\title{
Effects of Changing Irrigation Practices on the Ground-Water Hydrology of the Santa Isabel- Juana Díaz Area, South Central Puerto Rico
}

By Orlando Ramos-Ginés

U.S. GEOLOGICAL SURVEY

Water-Resources Investigations Report 91-4183

Prepared in cooperation with the

PUERTO RICO DEPARTMENT OF AGRICULTURE 


\section{U.S. DEPARTMENT OF THE INTERIOR BRUCE BABBITT, Secretary}

\section{U.S. GEOLOGICAL SURVEY}

Robert M. Hirsch, Acting Director

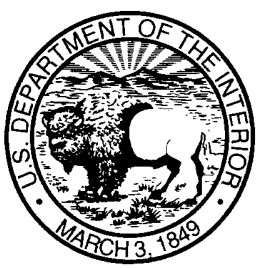

For additional information write to:

District Chief

U.S. Geological Survey

P.O. Box 364424

San Juan, Puerto Rico 00936-4424
Copies of this report can be purchased from:

U.S. Geological Survey Earth Science Information Center Open-File Reports Section, MS 517 Box 25286, Denver Federal Center Denver, CO 80225 


\section{CONTENTS}

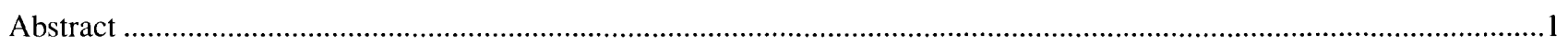

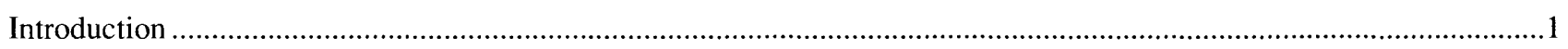

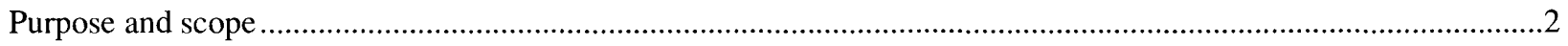

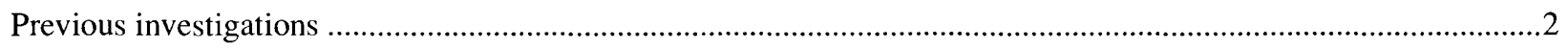

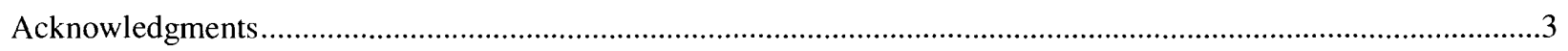

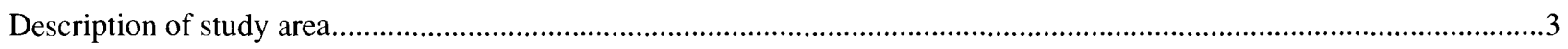

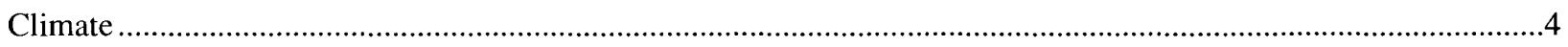

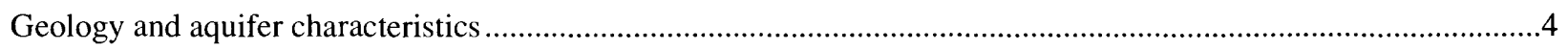

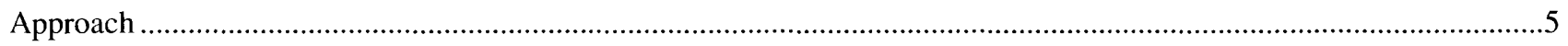

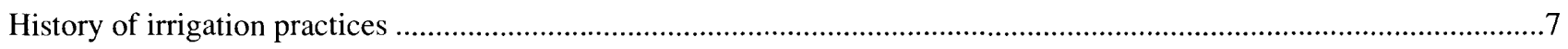

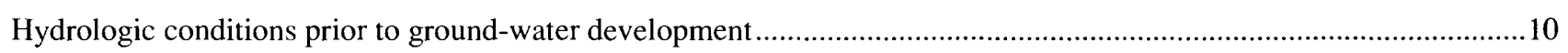

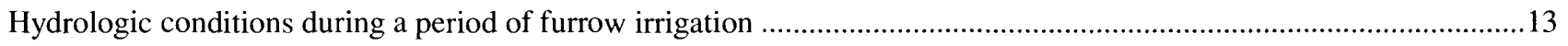

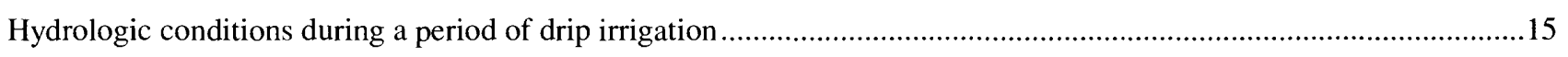

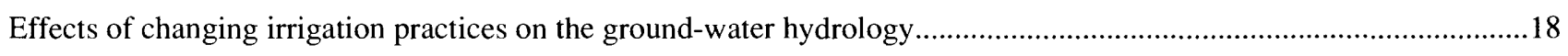

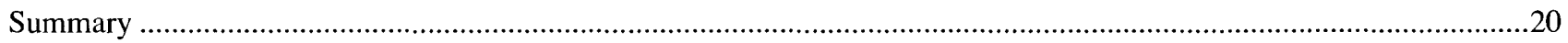

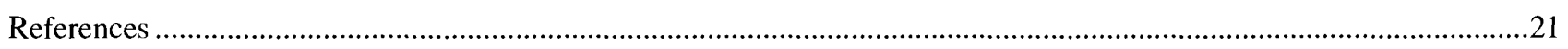

\section{FIGURES}

1. Map showing location of the study area and data-collection sites .........................................................................

2. Graph showing mean-monthly and mean-annual rainfall and pan

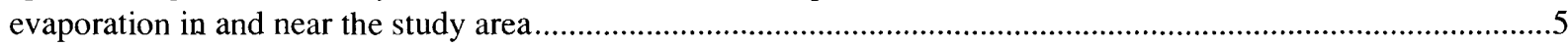

3-8. Map showing:

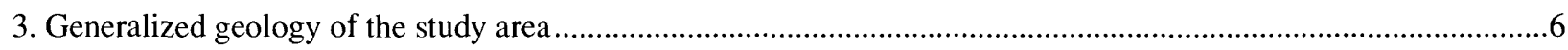

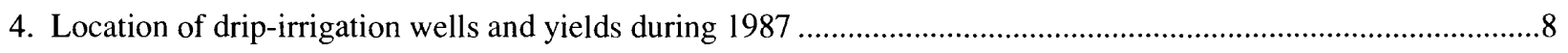

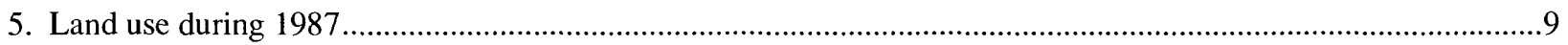

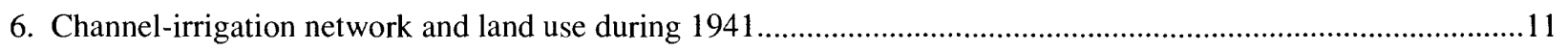

7. Estimated ground-water level contours and general directions of

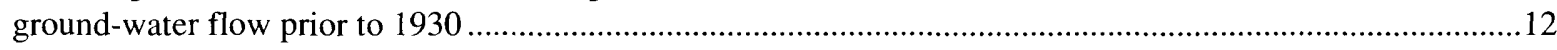

8. Ground-water levels and general directions of ground-water flow

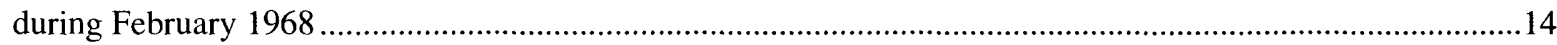

9. Graph showing mean daily ground-water level in monitoring wells during 1985 to 1987 , and long-term mean daily ground-water level at Calabreñas 1 well.

10. Map showing ground-water levels and general directions of ground-water flow during March and April 1987

11. Graph showing net contribution of streams to the aquifer recharge during April 1987 ..........................................18

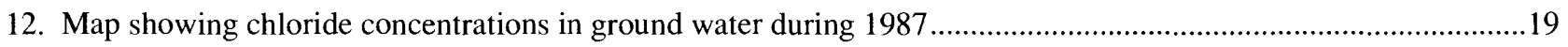

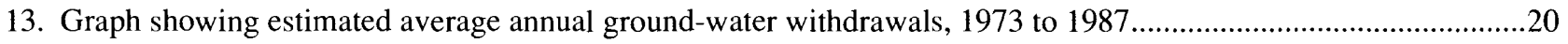




\section{TABLES}

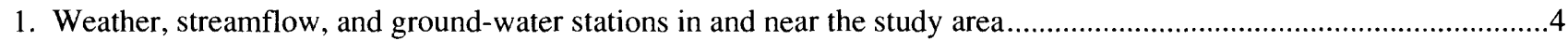

2. Summary of aquifer recharge and discharge prior to ground-water development and during periods of furrow irrigation and drip irrigation.

CONVERSION FACTORS AND ACRONYMS

\begin{tabular}{rcl} 
Multiply & By & To obtain \\
\hline inch (in.) & 25.4 & millimeter \\
foot (ft) & 0.3048 & meter \\
mile (mi) & 1.609 & kilometer \\
acre & 4,047 & square meter \\
square mile (mi $\left.{ }^{2}\right)$ & 2.590 & square kilometer \\
million gallons (Mgal) & 3,785 & cubic meter \\
gallon per minute (gal/min) & 0.003785 & cubic meter per minute \\
million gallons per day (Mgal/d) & 3,785 & cubic meter per day \\
foot per day (ft/d) & 0.3048 & meter per day \\
foot squared per day (ft $\left.{ }^{2} / \mathrm{d}\right)$ & 0.09290 & meter squared per day \\
\hline
\end{tabular}

Acronyms used in this report:

milligram per liter $(\mathrm{mg} / \mathrm{L})$ 


\title{
Effects of Changing Irrigation Practices on the Ground-Water Hydrology of the Santa Isabel-Juana Díaz Area, South Central Puerto Rico
}

\author{
By Orlando Ramos-Ginés
}

\begin{abstract}
An assessment of the effects of changes in irrigation practices on the ground-water resources in the Santa IsabelJuana Díaz area of southern Puerto Rico was made by the U.S. Geological Survey, in cooperation with the Puerto Rico Department of Agriculture during 1984 to 1987 . The study area, which is located in the relatively dry south central coastal plain of Puerto Rico, is largely used for agriculture and much of the area is irrigated.
\end{abstract}

Prior to 1930 , the principal water-supply source for irrigation was supplied by a complex channel-pond system from surface-water sources outside the study area. A small amount of ground water from the alluvial aquifer within the study area also was used for irrigation. Recharge from water applied to the fields and discharge by ground-water flow to the sea were the major water-budget components prior to the intensive development of the ground-water resources in the area. Recharge from irrigation was estimated to be 18.7 million gallons per day and the ground-water flow to sea was estimated to be 17 million gallons per day.

Development of the ground-water resources after 1930 resulted in a substantial increase in irrigation, primarily furrow irrigation. The surface water, supplied by the complex channel-pond system, continued to be used and groundwater withdrawals increased substantially. By 1968, groundwater recharge from irrigation water applied to the fields and discharge by pumpage became the two major components of the water budget. From 1966 through 1968, recharge from irrigation water was estimated to be 37 million gallons per day and the pumpage was about 77.3 million gallons per day. Saltwater intrusion occurred during this period as a result of the large ground-water withdrawals and low groundwater levels.

Concern about the saltwater intrusion and declining water levels, and a shift away from sugarcane as the principal crop, led to substantial reductions in ground-water withdrawals during the 1970's and a gradual conversion from furrow irrigation to the more efficient drip irrigation. By 1987, drip irrigation had become the principal method of irrigation in the study area, and the channel-pond system of irrigation had, for the most part, been discontinued. The estimated aquifer recharge from irrigation in 1987 was about 6.6 million gallons per day. This recharge occurred primarily in the remaining sugarcane fields, where furrow irrigation was still practiced. Although aquifer recharge had been reduced as a result of the conversion from furrow to drip irrigation, water levels in the aquifer were higher in 1987 than in 1968, because of the large reduction in ground-water withdrawals and subsequent recovery of ground-water levels.

In 1987, chloride concentrations in ground water near the seashore were lower than concentrations in the same area during 1966 to 1968 , because of the increased ground-water flow to the sea. Chloride concentrations were about 40 milligrams per liter at distances of less than one mile from shore in 1987, compared with 250 milligrams per liter at about the same distance during 1966 to 1968 .

\section{INTRODUCTION}

Changing irrigation practices have caused substantial changes in the ground-water hydrology in south central Puerto Rico. Prior to 1930 , the principal water supply for agriculture was from surface-water sources outside the study area and was made available to farmers through a complex channel-pond system. After about 1930, however, the ground-water resources of the area were developed to meet the growing demand for water for irrigation. By the late 1960 's, large withdrawals of ground water had caused water-level declines and resulted in saltwater intrusion into the aquifer near the coast. 
The standard irrigation method in the Santa Isabel-Juana Díaz area of Puerto Rico was furrow irrigation until about 1985. Since that time, the primary method of irrigation has been drip irrigation. Drip irrigation, which more effectively uses available ground-water resources and is more suitable for the new type of crops grown in the area, began to gradually replace furrow irrigation in the 1970's. Until about 1985, sugarcane was the most important crop in the study area. However, a decline in the worldwide sugar market prices and a shift in the agricultural priorities of the government of Puerto Rico resulted in almost a complete replacement of sugarcane with vegetable and fruit crops by 1987.

During 1986 and 1987, retention ponds associated with the channel system were destroyed. This channel-pond network provided a significant amount of recharge to the aquifer (Giusti, 1971b). The change to drip-irrigation methods and the resulting reduction in recharge to the aquifer caused the Puerto Rico Department of Agriculture to be concerned about the potential for ground-water level declines and saltwater intrusion problems.

In response to the concern about the potential effect of the new irrigation technique, on the ground-water resources of the area, the U.S. Geological Survey initiated a cooperative study with the Puerto Rico Department of Agriculture in 1984 to describe how the changes in irrigation techniques have influenced the ground-water hydrology in the Santa IsabelJuana Díaz area.

\section{Purpose and Scope}

The purpose of this report is to describe the effects of changing irrigation practices on the ground-water hydrology in the Santa Isabel-Juana Díaz area. The report describes hydrologic conditions and presents estimates of the recharge to and discharge from the alluvial aquifer during three periods in which the amount and source of water used for irrigation differed. The three periods were: (1) a period of furrow irrigation prior to ground-water development, when water for irrigation was supplied mainly from surface-water sources outside the study area; (2) a period of furrow-irrigation, when ground water and surface water were used; and (3) a period of drip irrigation, when the water used for irrigation came primarily from the alluvial aquifer within the study area.

\section{Previous Investigations}

The general hydrologic conditions for the south coast of Puerto Rico were first documented by McGuinness (1948) as part of a comprehensive inventory of the ground-water resources of Puerto Rico. The McGuinness (1948) report was based on well data collected during a comprehensive well inventory of the Island (McGuinness, 1946) and included general descriptions of the geology and hydrology of the Santa Isabel-Juana Díaz area.

The general hydrologic conditions for Puerto Rico were also summarized by Bogart and others (1964). The report utilized well data from an updated well inventory (Ward and Truxes, 1964) and presented general descriptions of the water-bearing units, well depths, well capacities, and general water-quality characteristics. Giusti (1968 and 1971b) described the hydrology in the area between the Río Descalabrado and the Río Jacaguas and in the area between the Río Jueyes and the Río Descalabrado.

Studies of ground-water levels and chloride concentrations in the study area include those by H. Colón-Ramos (U.S. Geological Survey, unpublished data, 1972), Colón-Ramos and Colón-Dieppa (1981), Colón-Dieppa and González (1981), J.R. Díaz (U.S. Geological Survey, unpublished data, 1974), J.R. Díaz (1974, 1977a, 1977b, 1979a, and 1979b), J.E. Heisel (U.S. Geological Survey, unpublished data, 1973), Heisel and González (1976), D.G. Jordan (U.S. Geological Survey, unpublished data, 1974), and F. Quiñones-Marquéz (U.S. Geological Survey, unpublished data, 1971). These studies indicated that during some years (1968, 1969, 1973, and 1974) the water table was below sea level at many sites. The lowest water level reported was 20 feet (ft) below sea level, which was measured near Santa Isabel (D.G. Jordan, U.S. Geological Survey, unpublished data, 1974; Díaz, 1974a). The low water levels caused the inland movement of the saline-freshwater interface as documented by an increase of chloride concentrations in the aquifer.

Bennett (1976) constructed an electrical analog model of the south coast water-table aquifer. Heisel and González (1976) used this model to evaluate the ground-water conditions in the south coast during simulated periods of extended drought, approximating the drought of 1971 to 1973; and to evaluate the possibility of using treated waste water to recharge the aquifer. The maximum change in water level of $24 \mathrm{ft}$ simulated in their study underestimated the changes observed by Díaz (1974) during 1974. Heisel and González (1979, p. 99-100) suggested that the use of treated waste water to recharge the aquifer was a viable solution to the decline in ground-water levels during drought conditions, but indicated that the quality of the water used could affect the quality of the ground water.

The geology of the Santa Isabel-Juana Díaz area has been discussed in detail by Glover (1961a, 1961b and 1971), Glover and Mattson (1973), Krushensky and Monroe (1975), and Monroe (1980). 


\section{Acknowledgments}

The author gratefully acknowledges the assistance and cooperation of the Puerto Rico Department of Agriculture personnel who provided historical information used to define the hydrologic conditions during the period prior to groundwater development. The author also is grateful to the many land owners that provided U.S. Geological Survey personnel access to their supply wells to make water-level measurements and collect water samples.

\section{DESCRIPTION OF STUDY AREA}

The Santa Isabel-Juana Díaz area, which comprises about 50 square miles $\left(\mathrm{mi}^{2}\right)$, is located on the south central coastal plain of Puerto Rico (fig. 1). The study area is bounded on the west by the Río Jacaguas, on the east by the Río Jueyes, on the north by an alluvium-bedrock contact, and on the south by the Caribbean Sea. The topography of the study area is nearly flat, with an average slope of about 10 feet per mile (ft/mi).

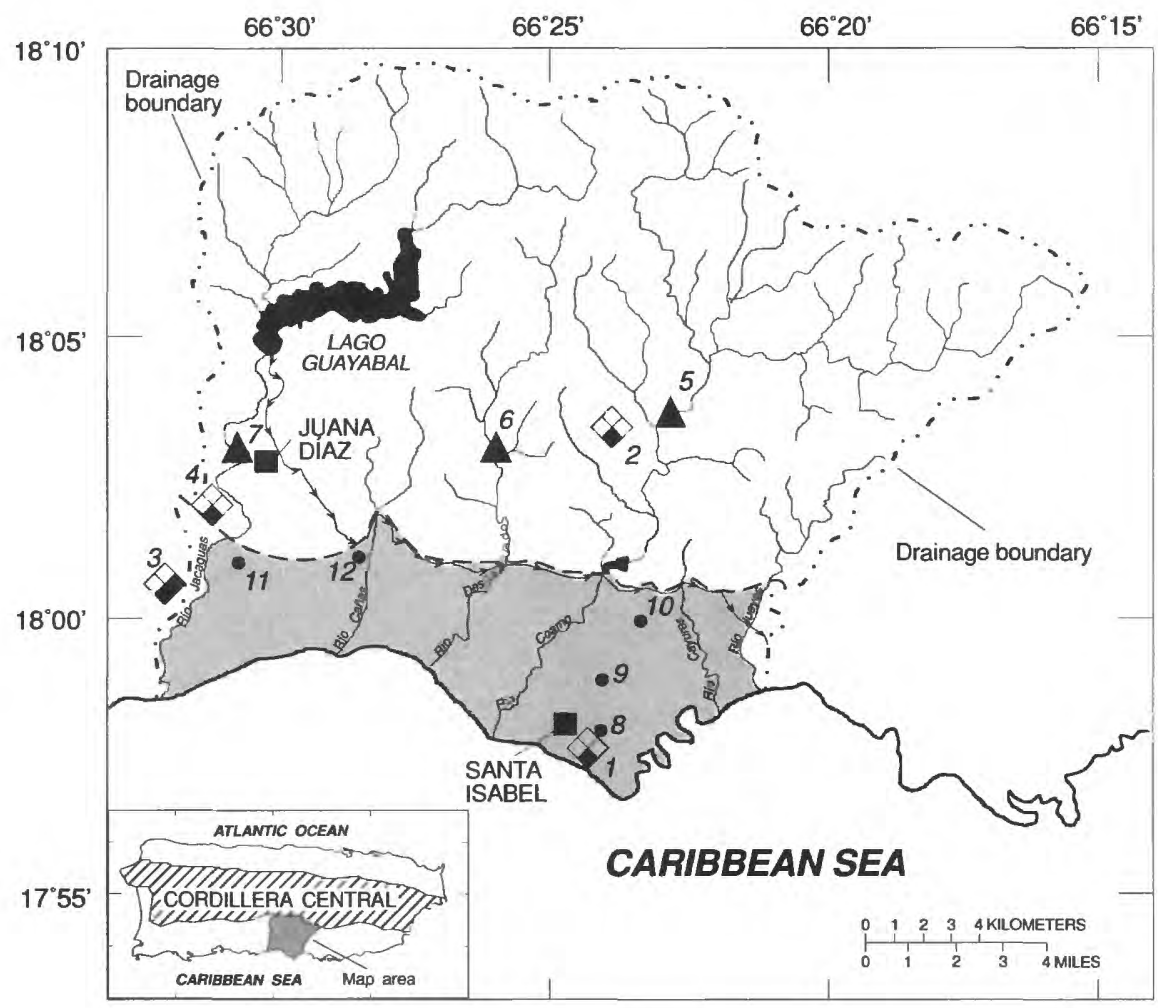

EXPLANATION

STUDY AREA

RAINFALL STATION AND NUMBER ON TABLE 1

RAINFALL AND PAN EVAPORATION STATION AND NUMBER ON TABLE 1

$\mathbf{A}^{7}$ STREAMFLOW STATION AND NUMBER ON TABLE 1

-11 OBSERVATION WELL, EQUIPPED WITH RECORDER, AND NUMBER ON TABLE 1

$\rightarrow \quad$ CANAL DE JUANA DÍAZ

- - - ALLUVIUM-BEDROCK CONTACT

.... DRAINAGE BASIN BOUNDARY

Figure 1. Location of the study area and data-collection sites. 
Six streams, the Río Jacaguas, the Río Cañas, the Río Descalabrado, the Río Coamo, the Río Cayures, and the Río Jueyes, flow into the study area from the north (fig. 1). The streams drain part of the southern slopes of the high-rainfall Cordillera Central mountain range and have moderate to high streamflows. The flow of the Río Jacaguas, one of the three major streams (the Río Jacaguas, the Río Descalabrado, and the Río Coamo), is controlled by a dam at Lago Guayabal.

The major land use in the study area is agriculture. In 1987, a total of 25,000 acres were used for agriculture, primarily for vegetable and fruit production. The remaining area includes urban areas (5,300 acres), wetlands (1,000 acres), and grass lands (640 acres).

\section{Climate}

The climate of the study area is semi-arid, and is characterized by two wet periods (May and October-November) and high rates of evaporation throughout the year. Approximately 17 and 50 percent of the annual rainfall in 1985-87 occurred in May and during October-November, respectively (fig. 2). The long-term average-annual rainfall (based on the 30-year period,
1955-84) in the study area (site 1) is 32 inches (in.). During 1985-87, the average-annual rainfall at site 1 was 45 in., which was 40 percent higher than the 30 -year average. The average pan evaporation for 1985-87 at site 3 was 83 in., which was 2 in. higher than the 10-year average-annual pan evaporation (1978-87) of 81 in., and more than twice the 30-year averageannual rainfall.

Rainfall at sites 2 and 4 in the headwaters of the Río Coamo and the Río Jacaguas generally is greater than rainfall in the study area. The 30 -year average rainfall at sites 2 and 4 were 0.8 and $9.8 \mathrm{in}$. greater than the 30-year average-annual rainfall at site 1 (fig. 2). During 1985-87, the average-annual rainfall at site 4 was $51.9 \mathrm{in}$, which is 24 percent higher than the 30 -year average and 15 percent higher than the average-annual rainfall at site 1 for the same period.

\section{Geology and Aquifer Characteristics}

The Santa Isabel-Juana Díaz area is underlain by three main lithologic units. From shallowest to deepest, these units are: (1) the alluvial deposits of Quaternary age, (2) the Juana Díaz Formation of Tertiary age, and (3) the volcanic rocks of

Table 1. Weather, streamflow, and ground-water stations in and near the study area shown in figure 1

[--- means no data available or inappropriate for weather stations; $\mathrm{mi}^{2}$, square miles]

\begin{tabular}{|c|c|c|c|c|c|}
\hline $\begin{array}{l}\text { Site } \\
\text { number } \\
\text { (fig. 1) }\end{array}$ & $\begin{array}{l}\text { Site } \\
\text { name }\end{array}$ & Latitude & Longitude & $\begin{array}{l}\text { Altitude } \\
\text { of land } \\
\text { surface } \\
\text { (in feet } \\
\text { above mean } \\
\text { sea level) }\end{array}$ & $\begin{array}{l}\text { Stream drainage } \\
\text { area (in } \mathrm{mi}^{2} \text { ), } \\
\text { or well screen } \\
\text { interval (in } \\
\text { feet below } \\
\text { land surface) }\end{array}$ \\
\hline \multicolumn{6}{|c|}{ Weather Stations: } \\
\hline $\begin{array}{l}1 \\
2 \\
3 \\
4\end{array}$ & $\begin{array}{l}\text { Santa Isabel } 2 \text { ENE } \\
\text { Coamo 4S } \\
\text { Ponce 4E } \\
\text { Juana Díaz Camp }\end{array}$ & $\begin{array}{l}175800 \\
180340 \\
180100 \\
180200\end{array}$ & $\begin{array}{l}662400 \\
662320 \\
663200 \\
663100\end{array}$ & $\begin{array}{r}30.00 \\
250.00 \\
70.00 \\
200.00\end{array}$ & $\begin{array}{l}--- \\
--- \\
--\end{array}$ \\
\hline \multicolumn{6}{|c|}{ Streamflow Stations: } \\
\hline $\begin{array}{l}5 \\
6 \\
7\end{array}$ & $\begin{array}{l}\text { Río Coamo near Coamo } \\
\text { (50106500) } \\
\text { Río Descalabrado near } \\
\text { Los Llanos (50108000) } \\
\text { Río Jacaguas at } \\
\text { Juana Díaz (50111500) }\end{array}$ & $\begin{array}{l}180352 \\
180308 \\
180316\end{array}$ & $\begin{array}{l}662210 \\
662534 \\
663040\end{array}$ & $\begin{array}{l}260.00 \\
220.00 \\
131.00\end{array}$ & $\begin{array}{l}46.00 \\
12.90 \\
49.80\end{array}$ \\
\hline \multicolumn{6}{|c|}{ Ground-Water Stations: } \\
\hline $\begin{array}{r}8 \\
9 \\
10 \\
11 \\
12\end{array}$ & $\begin{array}{l}\text { Jauca Felicia } \\
\text { Calabreñas-1 (USGS-87) } \\
\text { Paso Seco-7 } \\
\text { Fort Allen TW-1 } \\
\text { Amelia Drip }\end{array}$ & $\begin{array}{l}175759 \\
175829 \\
175943 \\
180048 \\
180057\end{array}$ & $\begin{array}{l}662315 \\
662322 \\
662248 \\
663022 \\
662825\end{array}$ & $\begin{array}{l}26.36 \\
35.32 \\
88.58 \\
36.34 \\
57.22\end{array}$ & $30-201$ \\
\hline
\end{tabular}



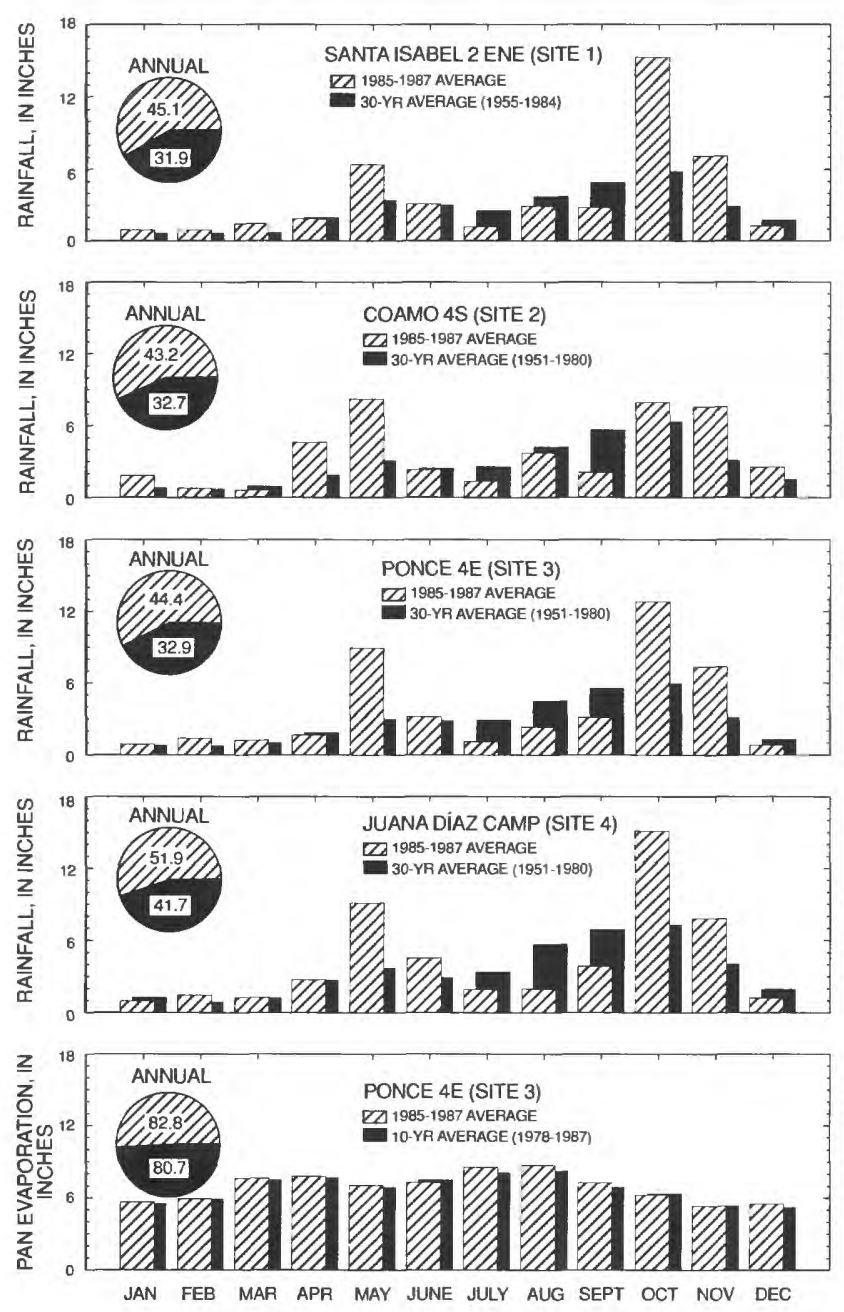

Figure 2. Mean-monthly and mean-annual rainfall and pan evaporation in and near the study area.

Tertiary to Cretaceous age (fig. 3). The rocks of the Juana Díaz Formation in the study area have low hydraulic conductivity (2.5 feet per day (ft/d)) and do not represent an important aquifer (Bennett, 1976, p. 16). The volcanic and igneous rocks that crop out in the uplands and that underlay the Juana Díaz Formation are hydraulically unimportant, because of the high degree of consolidation and lack of significant porosity. Beach sands and swamp deposits of Pleistocene and Holocene age are present along the coast, but are of limited areal extent.
The coalesced alluvial-fan deposits of Quaternary age constitute the principal aquifer in the study area, and are composed of layered to lenticular bodies of irregularly sorted, unconsolidated to poorly-consolidated clay, silt, sand, gravel, and rounded to angular boulders. Gravel content of the alluvium appears to be greater in the area between the Río Coamo and the Río Jueyes (Giusti, 1971b) than in other areas. In general, grain size decreases toward the coast where the amount of silt and clay within the alluvium is greater than in the inland deposits. The coarsest grained deposits are generally found north of Santa Isabel.

The thickness of the alluvium is highly variable. Locally, anomalously thick deposits of alluvial material are associated with bedrock faulting (R.A. Renken, U.S. Geological Survey, written commun., 1989). The thickness of the alluvial deposits generally is greatest in the area between the Río Descalabrado and the Río Cayures. The maximum thickness of alluvium is about $3,000 \mathrm{ft}$ at a site about $1 \mathrm{mile}(\mathrm{mi})$ west of Santa Isabel.

Depositional patterns of the alluvial aquifer appear to be a major factor controlling the hydraulics of this system (R.A. Renken, U.S. Geological Survey, written commun., 1989). The transmissivity values near the coast, where the aquifer is under semi-confined or confined conditions, are fairly uniform. Finegrained deposits in the upper part of the alluvium restrict the vertical movement of water and water generally is under artesian conditions. Therefore, changes in water levels have little effect on the transmissivity of the aquifer in areas near the coast.

Transmissivity of the alluvial aquifer in the study area ranges from 5,000 to $100,000 \mathrm{ft}^{2} / \mathrm{d}$ (F. Gómez-Gómez, U.S. Geological Survey, written commun., 1989). Transmissivity values of the alluvial aquifer were estimated from specific capacity tests of wells completed prior to 1976 using empirical equations developed by Theis (1963) and Brown (1963). In general, the transmissivity is highest northeast of Santa Isabel and decreases toward the coast as a result of increased amounts of silt and clay in the alluvium. The alluvial aquifer decreases in productivity at depths greater than $250 \mathrm{ft}$, probably because of decreased transmissivity related to increased amounts of silt and clay (Giusti, 1968, p. 29).

\section{APPROACH}

Hydrologic conditions prior to ground-water development (prior to 1930) were determined from available ground-water and surface-water data. These data included ground-water levels and withdrawals (1924 to 1930), surface-water deliveries from sources outside of the study area (Puerto Rico Energy and 


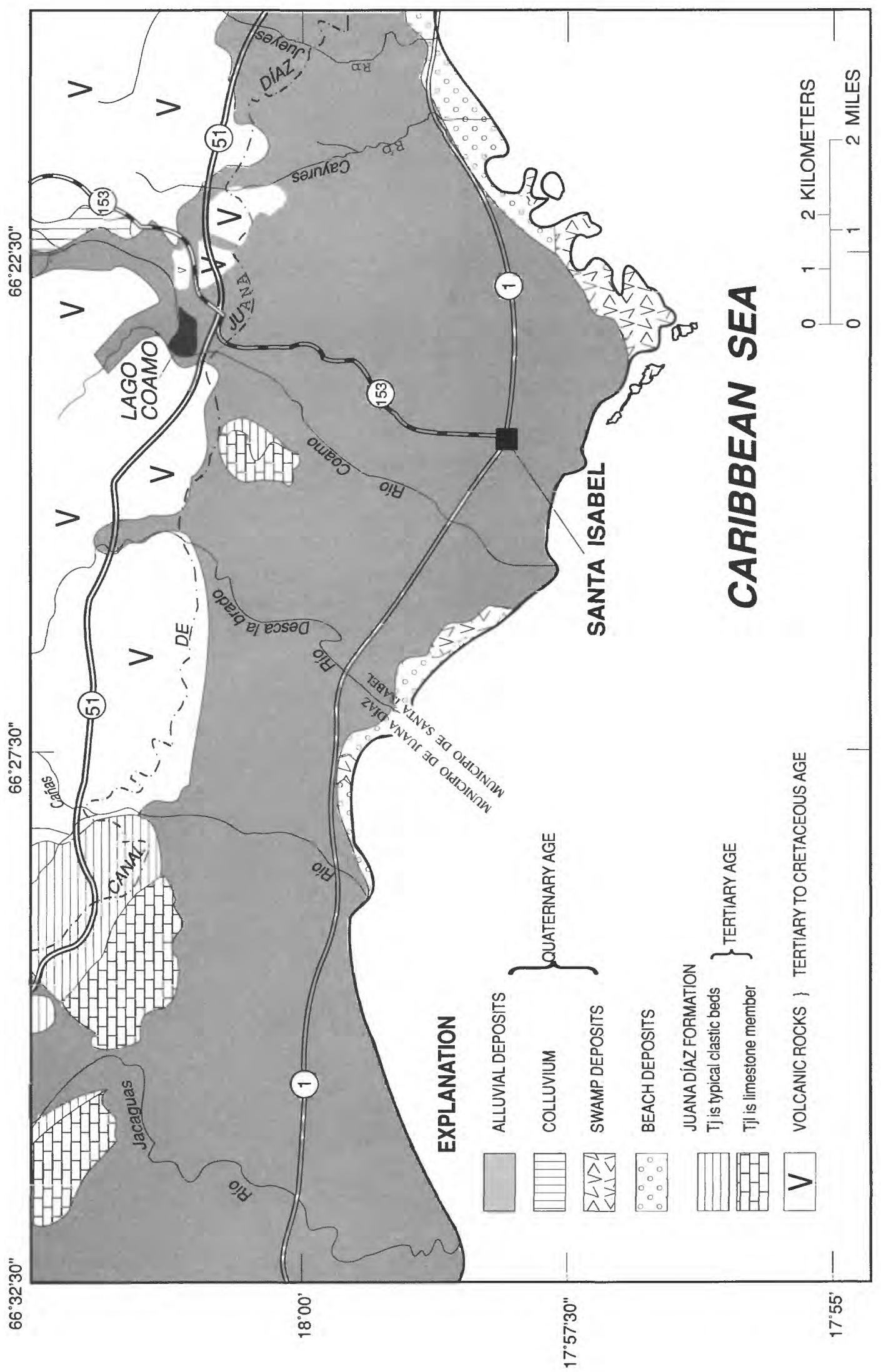

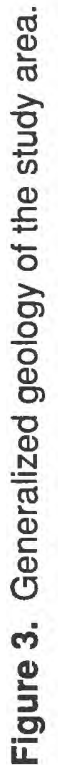


Irrigation Authority, unpublished data), and rainfall (1925 to 1930; U.S. Department of Agriculture, 1934). The data were used to estimate predevelopment water levels and the direction of ground-water movement in the aquifer, to estimate the aquifer hydraulic gradient near the coast, and to estimate the amount of ground-water flow to the sea. Net aquifer recharge by streamflow seepage was assumed to be 3.5 million gallons per day (Mgal/d) (see section 'Hydrologic Conditions Prior to Ground-Water Development'). Evapotranspiration was estimated as the difference between the inflow and outflow values of the water budget in the study area. The agricultural activities in the study area were determined from reports describing land use and irrigation techniques (Album de Oro de Puerto Rico, 1939; Luchetti, 1969; and the Puerto Rico Department of Agriculture, 1984).

Hydrologic conditions during a period of furrow irrigation, in which ground water was a major source of water used for irrigation, were characterized as those prevailing from 1966 to 1968. The information documented during this period was the most comprehensive found in the available literature. The hydrologic studies in the area between the Río Jacaguas and the Río Descalabrado during 1966 (Giusti, 1968) and in the area between the Río Jueyes and the Río Descalabrado in 1967 (Giusti, 1971b) were assumed to be representative of hydrologic conditions during the period in which furrow-irrigation practices were used and during which most of the water used for irrigation came from the ground-water system. The studies by Giusti $(1968,1971 b)$ formed the basis of the water-budget terms used for this period. The ground-water level data obtained in February 1968 (D.G. Jordan, U.S. Geological Survey, unpublished data, 1974) was assumed to be representative of the water-level conditions in 1966-68. The data that Jordan used to prepare the water-level map were collected along the south coast of the Island in February 1968.

Ground-water level surveys and reconnaissance of the hydrologic conditions were used with previously published information to describe existing conditions in 1987 and to assess the effects of the changes from furrow to drip irrigation. Streamflow measurements were made at selected sites to determine the amount of water that infiltrates to and seeps from the aquifer. Flow measurements also were made in the Canal de Juana Díaz to determine the volume of flow diverted to the study area. Surface-water stations, at which stage and discharge were continuously monitored, were constructed at the three principal streams flowing into the study area: the Río Jacaguas, the Río Descalabrado, and the Río Coamo (sites 7, 6, and 5; fig. 1). An observation well was drilled and instrumented with a recorder to monitor ground-water levels in the alluvial aquifer (site 11, fig. 1). Three abandoned production wells also were instrumented with recorders ( $\operatorname{sites} 8,10$, and 12; fig. 1). Ground-water level data that had been collected since 1966 at site 9 (fig. 1) were compiled and used to assess longterm changes in ground-water levels. Additional streamflow and ground-water level measurements made in March and April 1987 (Rodríguez-del-Río and Gómez-Gómez, 1990) were used to characterize the average hydrologic conditions in the study area in 1987.

\section{HISTORY OF IRRIGATION PRACTICES}

Irrigation practices in the Santa Isabel-Juana Díaz area have changed substantially over time. During the predevelopment period (prior to 1930), the principal source of water used for irrigation was surface water from sources outside the study area. Only a small amount of ground water from the alluvial aquifer within the study area during this period was used for irrigation. Ground-water withdrawals increased substantially after 1930, however, to supply water to new farms. During the 1970 's and 1980's, concern about declining ground-water levels led to a gradual shift from furrow irrigation to drip irrigation. By 1986, drip irrigation was the primary type of irrigation in the area and sugarcane had been replaced with vegetables and fruit crops. As a result of the shift to drip irrigation, ground-water withdrawals have decreased and the dependance on surface water has declined.

The drip-irrigation system is an automated, high frequency, low volume application method that is both technically and economically efficient (Yamauchi, 1984). Drip irrigation provides enough water to meet the needs of plants but minimizes overwatering plants and evaporation losses.

The drip-irrigation system, as used in the study area during 1987 , is designed to deliver $0.3 \mathrm{in}$. of water per day during cultivation (Puerto Rico Department of Agriculture, 1984). Fortythree wells in the study area were used to supply water for drip irrigation (fig. 4). Pumping rates for these wells ranged from 25 to 1,500 gallons per minute ( $\mathrm{gal} / \mathrm{min}$ ) (W. Allison, Puerto Rico Department of Agriculture, written commun., 1987) and averaged $830 \mathrm{gal} / \mathrm{min}$. The drip-irrigation system was used to irrigate about $10 \mathrm{mi}^{2}$ of land planted in vegetables and fruit crops (fig. 5).

The wells used with the drip-irrigation method were not pumped continuously throughout the year. Although all 43 wells were used for drip irrigation in 1987, not all were pumping simultaneously because some of the wells are connected to a common distribution system. Irrigation and harvesting often take place at different times in different locations throughout the study area, and only about 25 percent 


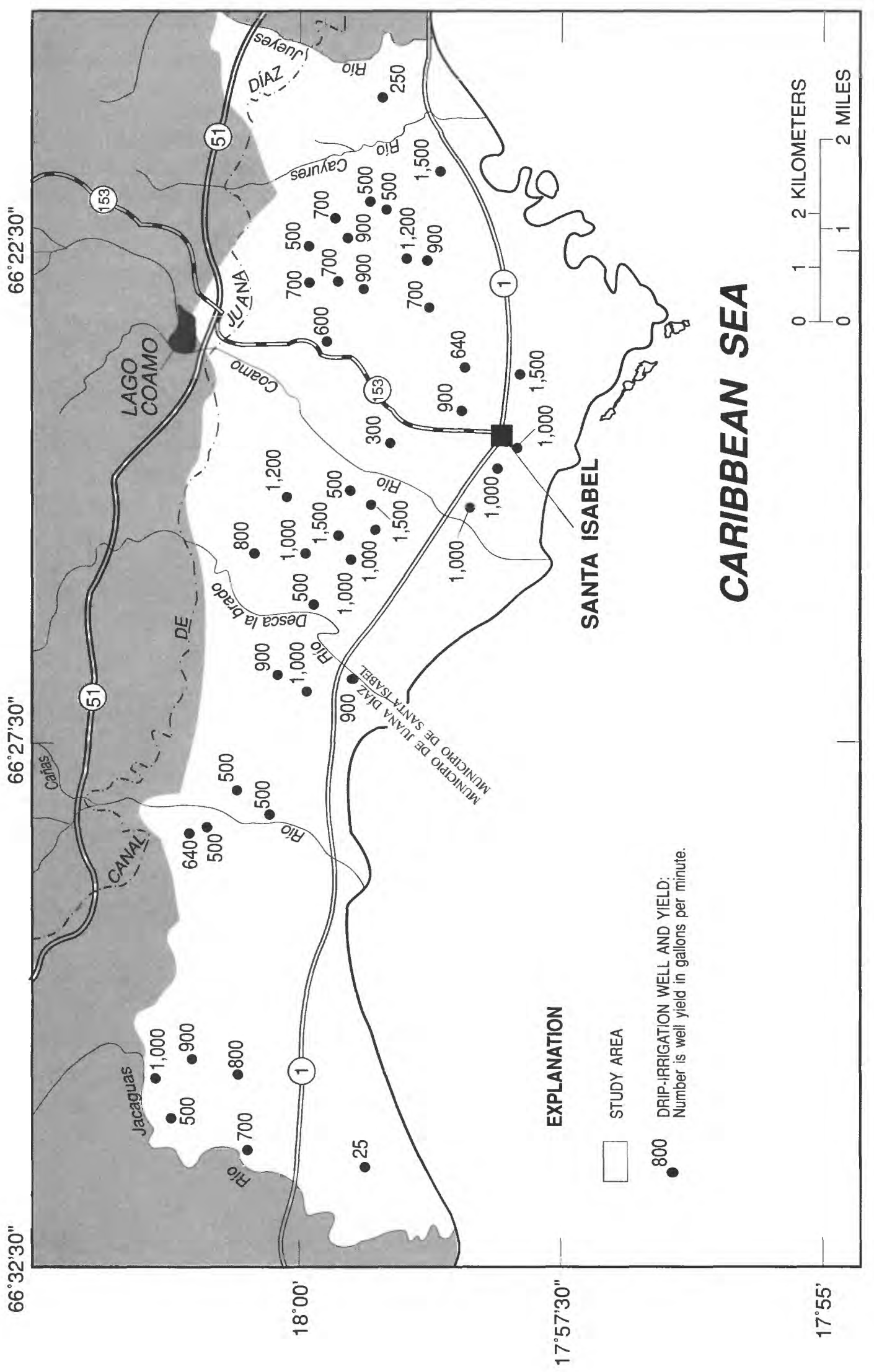

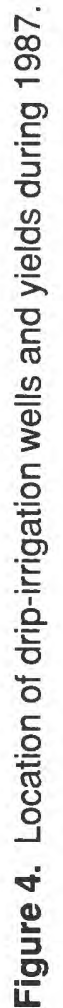




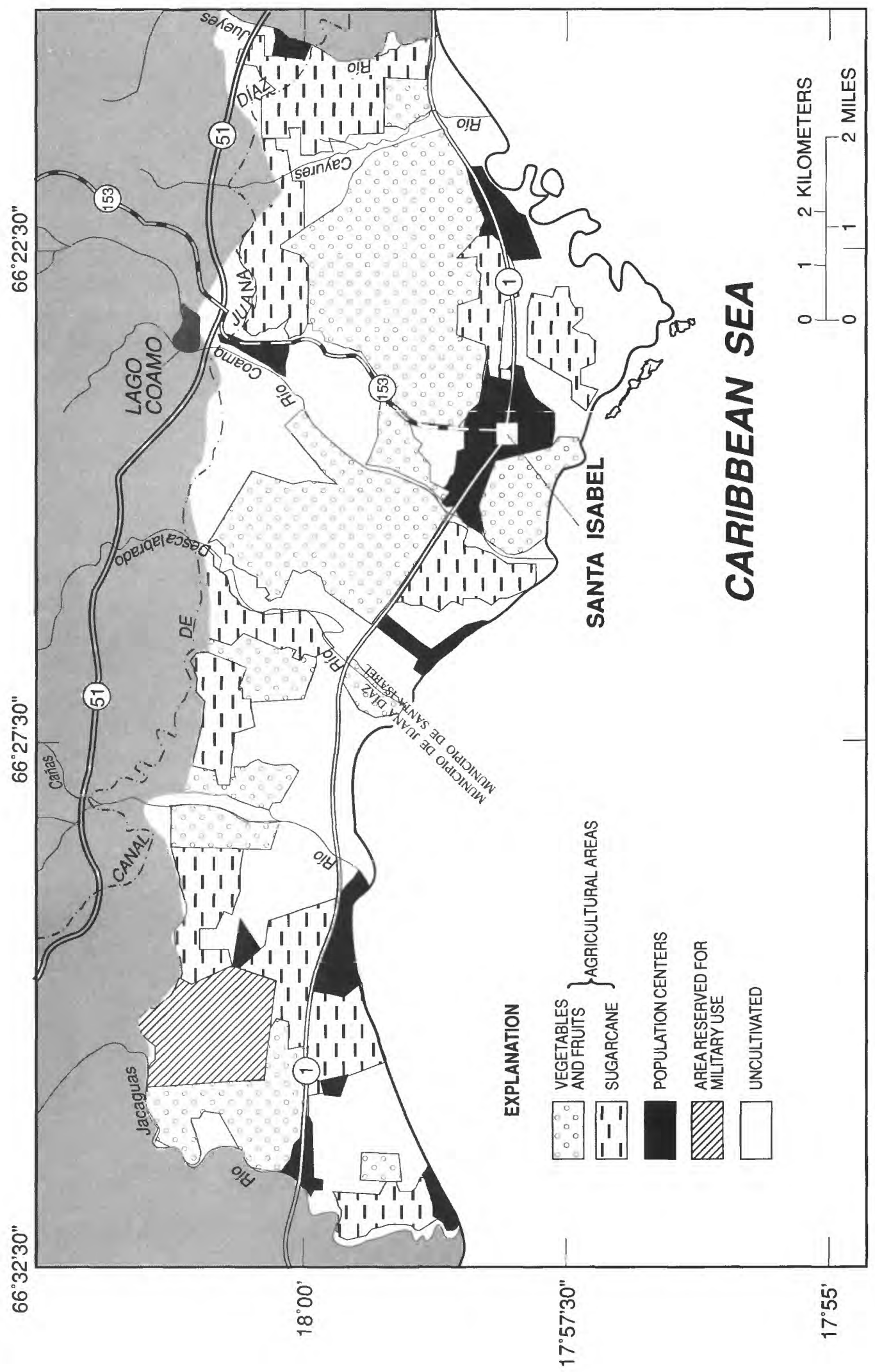

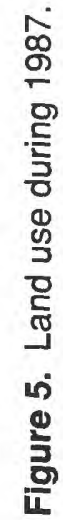


of the drip-irrigation wells are actively pumping at any given time. When in use, the wells operated about 8 hours per day during the two crop cycles of about 100 days per cycle (F. Gómez-Gómez, U.S. Geological Survey, oral commun., 1989).

\section{HYDROLOGIC CONDITIONS PRIOR TO GROUND-WATER DEVELOPMENT}

Hydrologic conditions in the study area prior to groundwater development are defined as those existing prior to 1930 . Ground-water development before 1930 was limited, because electrical power was not available in much of the area and the water demand for sugarcane irrigation was mainly satisfied by diverted streamflow throughout a complex channel-pond irrigation system constructed prior to 1900 (fig. 6). This channel system diverted surface water from Lago Guayabal at the headwaters of the Río Jacaguas and from Lago Coamo through Canal de Juana Díaz (fig. 1). Ground-water withdrawals in the area were not substantial until after 1930, when the extension of electrical power to agricultural areas made the use of ground water for irrigation much more economical.

Several assumptions were necessary to estimate predevelopment ground-water recharge. First, 10 percent ( 2.8 inches per year (in/yr); $6.7 \mathrm{Mgal} / \mathrm{d}$ ) of the average-annual rainfall for $1925-30$ (28 in/yr) in the study area (site 1, fig. 1) was assumed to recharge the aquifer. This recharge rate is the maximum computed rainfall recharge for alluvial aquifers in Puerto Rico reported by Giusti $(1971 \mathrm{a}, \mathrm{b})$. Thirty percent of the applied irrigation water (ground and surface water) was assumed to recharge the aquifer. This percentage is the same as that used by Giusti (1971a, p. 5; and 1971b, p. 25) to estimate water budgets in the study area.

The net aquifer recharge by streamflow seepage was assumed to be $3.5 \mathrm{Mgal} / \mathrm{d}$. This recharge value was based on results of simulation studies using a ground-water flow model developed for the area between the Río Cañas and the Río Jueyes (S. Torres-González, U.S. Geological Survey, written commun., 1989), which includes about 70 percent of the Santa Isabel-Juana Díaz area. For this study, the model simulated recharge for the smaller study area was assumed to represent recharge for the entire Santa Isabel-Juana Díaz area.

Accordingly, the amount of streamflow recharge used for the study area of this report should be considered a conservative estimate.

The diversions of surface water from sources outside the study area prior to 1930 indicate that streamflow in the study area was probably not sufficient for agricultural use. The volume of surface water diverted through the Canal de Juana
Díaz into the study area during 1930 was assumed to be equal to the amount diverted in 1954 (54 Mgal/d; Luchetti, 1969). This amount of water seems reasonable, because the amount of flow diverted through the Canal de Juana Díaz had not changed significantly from 1954 to 1985 (Sigfredo Torres-González, U.S. Geological Survey, oral commun., 1989).

Ground-water levels prior to 1930 were as high as $15 \mathrm{ft}$ above mean sea level at distances of less than $1 \mathrm{mi}$ inland from the seashore (fig. 7). The high water-levels were probably the result of aquifer recharge from water applied to fields during irrigation, particularly from the Canal de Juana Díaz (16.2 $\mathrm{Mgal} / \mathrm{d})$. Based on the water-level contours in figure 7, the direction of ground-water flow was toward the coast and toward the stream channels. The aquifer hydraulic gradient near the coast prior to 1930 averaged about $25 \mathrm{ft} / \mathrm{mi}$ east of the Río Descalabrado and about $17 \mathrm{ft} / \mathrm{mi}$ west of the Río Descalabrado.

Prior to 1930 , aquifer discharge occurred primarily by underflow to the sea, which did not permit the inland movement of seawater. Ground-water flow to the sea during predevelopment conditions was estimated to be $17 \mathrm{Mgal} / \mathrm{d}$. The estimate is based on the average hydraulic gradient near the coast to the west and to the east of the Río Descalabrado (17 and $25 \mathrm{ft} / \mathrm{mi}$, respectively); aquifer transmissivity values for each subarea $\left(4,000\right.$ and $11,000 \mathrm{ft}^{2} / \mathrm{d}$, respectively); and the cross-sectional length of each subarea $(42,500$ and $32,500 \mathrm{ft}$, respectively). Ground-water pumpage was probably as low as $8.4 \mathrm{Mgal} / \mathrm{d}$ for agriculture and $0.10 \mathrm{Mgal} / \mathrm{d}$ for public-water supply (McGuinness, 1948, p. 185-189). This estimate is based on an average pumpage of $1,200 \mathrm{gal} / \mathrm{min}$ for 110 days per year. This amount of water was pumped by means of about 16 steamoperated pumps powered by kerosene engines.

Seepage of water applied to the sugarcane fields was a major component of aquifer recharge during the period prior to 1930. Recharge of irrigation water to the aquifer in 1930 was estimated to be $18.7 \mathrm{Mgal} / \mathrm{d}$. This estimate of recharge includes 30 percent of the estimated $54 \mathrm{Mgal} / \mathrm{d}$ of surface water supplied in the complex channel-pond system in the study area and 30 percent of the estimated ground-water pumpage of $8.4 \mathrm{Mgal} / \mathrm{d}$.

Evapotranspiration, estimated as the residual of inflow and outflow terms of the water budget, was about $3.4 \mathrm{Mgal} / \mathrm{d}$. The total estimated aquifer recharge was $28.9 \mathrm{Mgal} / \mathrm{d}$, and the estimated aquifer outflow was $25.5 \mathrm{Mgal} / \mathrm{d}$ in discharge and 3.4 $\mathrm{Mgal} / \mathrm{d}$ in evapotranspiration.

Unpublished data in the files of the U.S. Geological Survey, indicate that prior to 1930 , chloride concentrations in water in the aquifer was less than $30 \mathrm{mg} / \mathrm{L}$ at distances of less than $1 \mathrm{mi}$ from the coast. The chloride concentrations in water from several wells located less than a mile from the coast ranged from 19 to $28 \mathrm{mg} / \mathrm{L}$. 


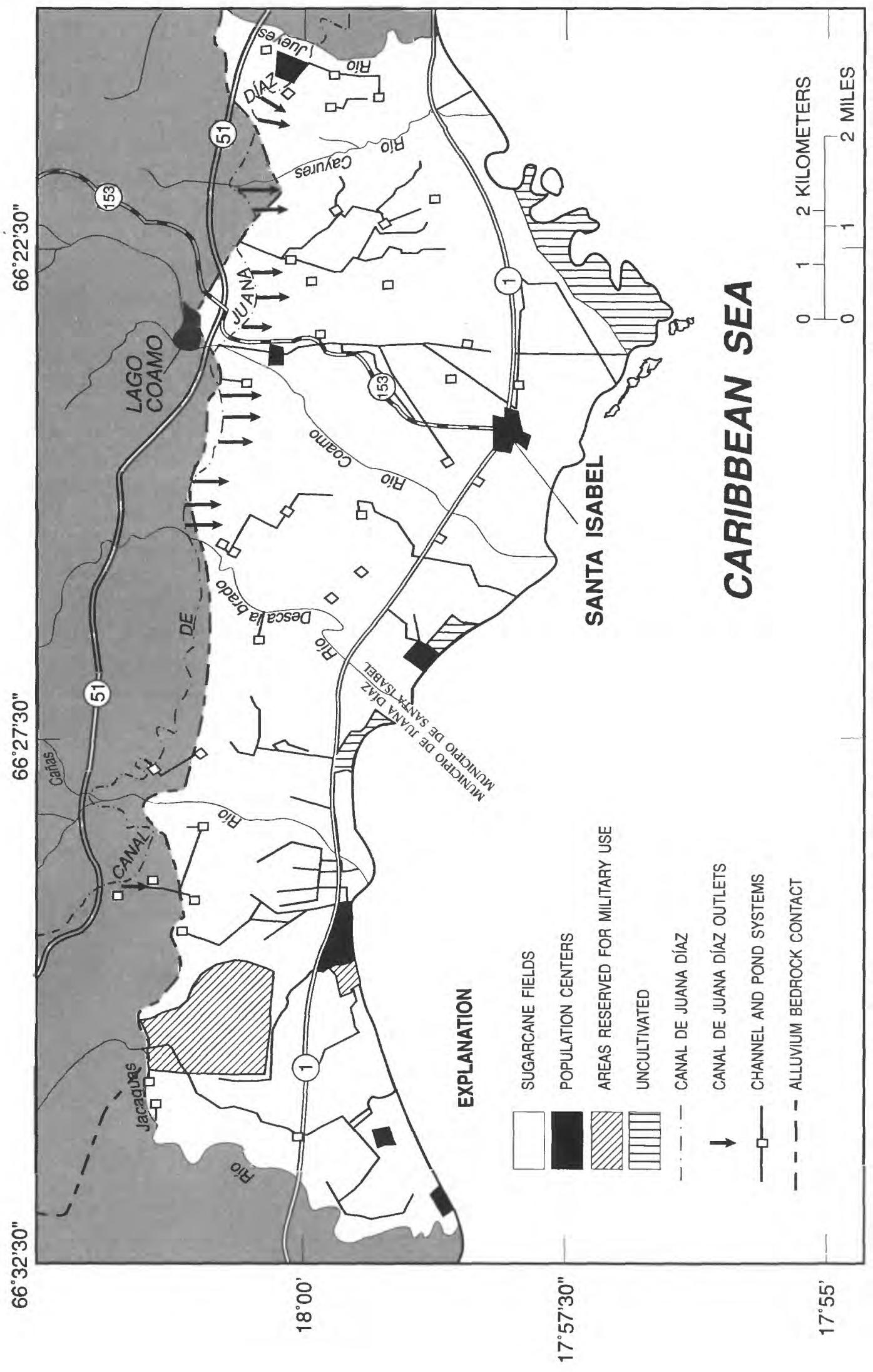

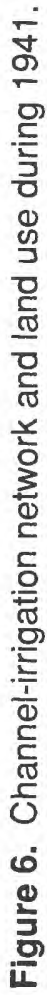




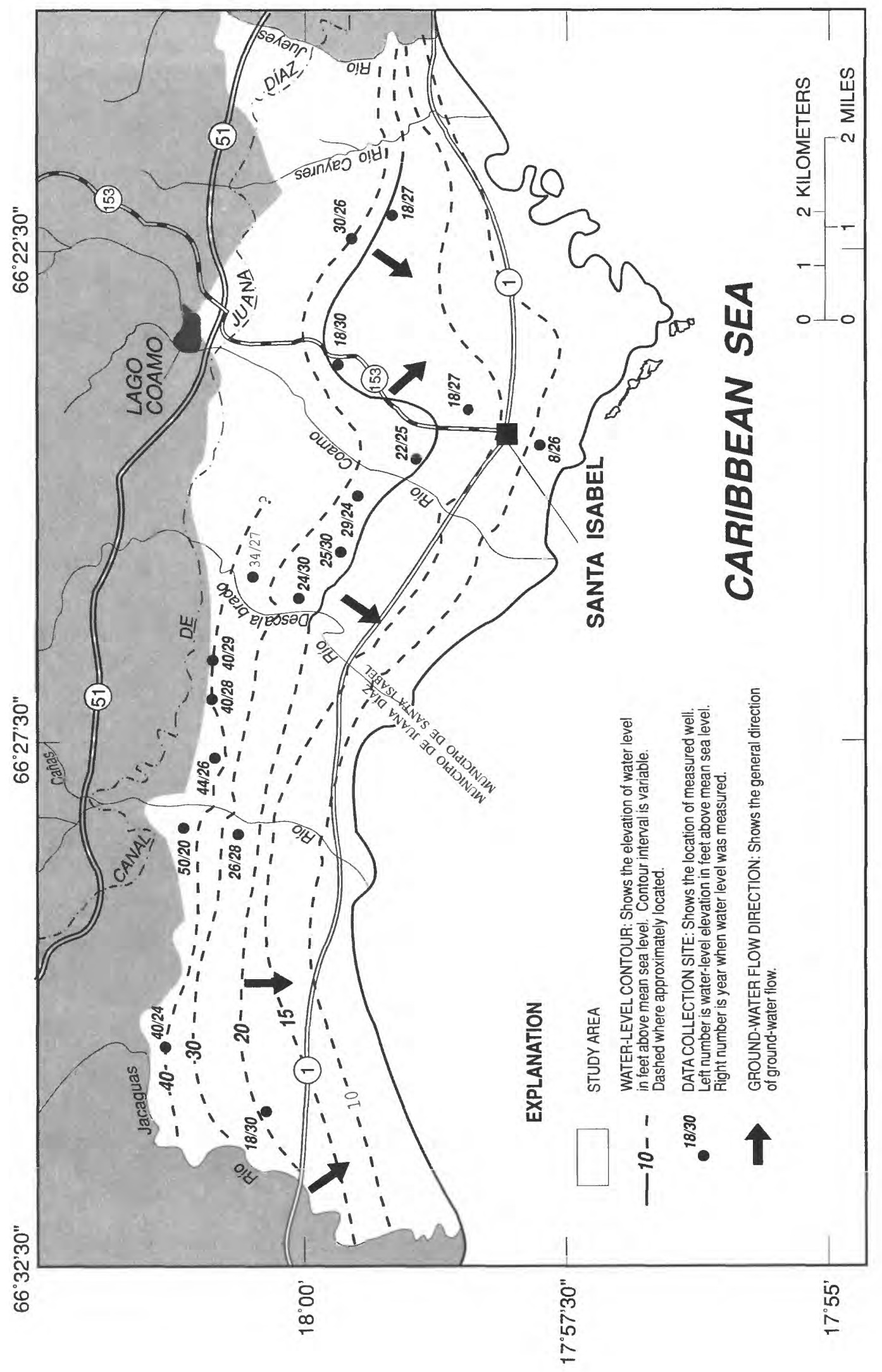

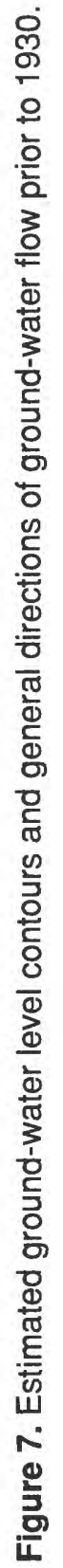




\section{HYDROLOGIC CONDITIONS DURING A PERIOD OF FURROW IRRIGATION}

Ground-water withdrawals from wells in the alluvial aquifer between 1930 and the late 1960's caused a decline in the ground-water levels. The decline in water levels also may have been due in part to the construction of dewatering channels to control the spread of malaria and reclaim additional land for sugarcane cultivation (Album de Oro de Puerto Rico, 1939, p. 385-467). For purposes of this report, the hydrologic conditions from 1966 to 1968 were assumed to be representative of conditions during a period of furrow irrigation when ground water was a major source of water used for irrigation. Groundwater data obtained in February 1968 (D.G. Jordan,U.S. Geological Survey, unpublished data, 1974) were used to depict the configuration of the water table in the alluvial aquifer during this period. Unpublished water-level data in the files of the U.S. Geological Survey indicate that water-levels continued to decline until about mid 1968. By September 1968, the ground-water levels had begun to recover and by January 1969 water levels generally were above mean sea level throughout the area. This increase in ground-water levels was probably the result of reduced pumping.

In February 1968, ground-water levels were below mean sea level throughout much of the agricultural area (fig. 8). The ground-water levels were as much as $20 \mathrm{ft}$ below mean sea level in areas of large ground-water withdrawals. The greatest decline in water level between 1930 and 1968 was observed in the area between the Río Descalabrado and the Río Jueyes. In 1966-68, ground-water withdrawals for furrow irrigation in the area between the Río Descalabrado and the Río Jueyes reduced the amount of water stored in the aquifer by about $9,120 \mathrm{Mgal}$ (Giusti, 1971b, p. 25).

The directions of ground-water flow in 1968 were different than those during predevelopment conditions for most parts of the study area. Although the direction of ground-water flow in the area between the Río Jacaguas and the Río Cañas was similar to that in 1930 , the direction of flow in the area between the Río Cañas and the Río Jueyes was toward the cones of depression centered around the areas of large ground-water withdrawals (fig. 8). The hydraulic gradient in the aquifer near the coast averaged about $15 \mathrm{ft} / \mathrm{mi}$ inland from the sea in the area to the east of the Río Descalabrado and about $4 \mathrm{ft} / \mathrm{mi}$ toward the coast in the area to the west of the Río Descalabrado.

In 1968, the major component of aquifer discharge was ground-water withdrawals for irrigation, which lowered the ground-water levels and reversed the hydraulic gradient near the coast in part of the study area. Ground-water withdrawals averaged about $77 \mathrm{Mgal} / \mathrm{d}$ for agricultural use and about 0.3
Mgal/d for public water supply. This was about 10 times the amount of water withdrawn in 1930 . The ground-water flow to the sea in 1968 was estimated to have decreased to about 0.5 $\mathrm{Mgal} / \mathrm{d}$ and was about 3 percent of the estimated flow to the sea in 1930. This estimate is based on the average hydraulic gradient toward the coast to the west of the Río Descalabrado of $4 \mathrm{ft} / \mathrm{mi}$, an aquifer transmissivity of $4,000 \mathrm{ft}^{2} / \mathrm{d}$, and a crosssectional length of $42,500 \mathrm{ft}$. In the area to the east of the Rio Descalabrado, the hydraulic gradient was reversed $(15 \mathrm{ft} / \mathrm{mi}$ from the coast inland) and there was no ground-water discharged to the sea.

Seawater had moved inland within the alluvial aquifer by 1966-68 as a result of the large ground-water withdrawals. Giusti (1971b, p.25) reported that chloride concentrations in water from a well located about $1 \mathrm{mi}$ from the coast in the area to the east of the Río Descalabrado increased from 50 milligrams per liter (mg/L) in 1960 to $250 \mathrm{mg} / \mathrm{L}$ in 1967. The chloride concentration near the coast increased from less than $30 \mathrm{mg} / \mathrm{L}$ prior to 1930 to $250 \mathrm{mg} / \mathrm{L}$ in $1966-68$.

About $5.3 \mathrm{Mgal} / \mathrm{d}$ of seawater flowed into the study area in $1966-68$ as a result of the decline in water levels to the east of the Río Descalabrado. This estimate is based on the average hydraulic gradient near the coast of $11 \mathrm{ft} / \mathrm{mi}$ to the east of the central portion of the Río Cañas and the Río Descalabrado area, an aquifer transmissivity of $10,000 \mathrm{ft}^{2} / \mathrm{d}$, and a cross-sectional length of $34,300 \mathrm{ft}$.

Recharge to the aquifer was higher in 1966-68 than during predevelopment conditions. Aquifer recharge was about 53.6 $\mathrm{Mgal} / \mathrm{d}$, which included an estimated $5.3 \mathrm{Mgal} / \mathrm{d}$ of seawater moving toward the areas of low water levels as discussed previously. The aquifer recharge was, however, about 32 percent less than the ground-water pumpage (77.3 Mgal/d).

Seepage of irrigation water into the aquifer was the major recharge component of the water budget in 1966-68 and totaled about $37 \mathrm{Mgal} / \mathrm{d}$ (Giusti, 1968, p. 37, and 1971b, p. 25). Recharge from applied ground-water accounted for about 23 $\mathrm{Mgal} / \mathrm{d}$ (30 percent of the $77 \mathrm{Mgal} / \mathrm{d}$ pumped from the aquifer), and recharge from surface water in diversion canals accounted for about $14 \mathrm{Mgal} / \mathrm{d}$ (30 percent of the $45 \mathrm{Mgal} / \mathrm{d}$ of surface water, diverted for irrigation). Streamflow seepage into the aquifer was about $5 \mathrm{Mgal} / \mathrm{d}$ and recharge from rainfall was estimated to average about $6.3 \mathrm{Mgal} / \mathrm{d}$, based on the assumption that 10 percent of the 1966-68 rainfall in the study area infiltrated the ground and reached the water table.

Evapotranspiration was estimated to be $0.2 \mathrm{Mgal} / \mathrm{d}$. This value was estimated based on the empirical relation developed by Bennett $(1976$, p. 62) in which the evapotranspiration from the aquifer is related to the depth to water. The estimated value 


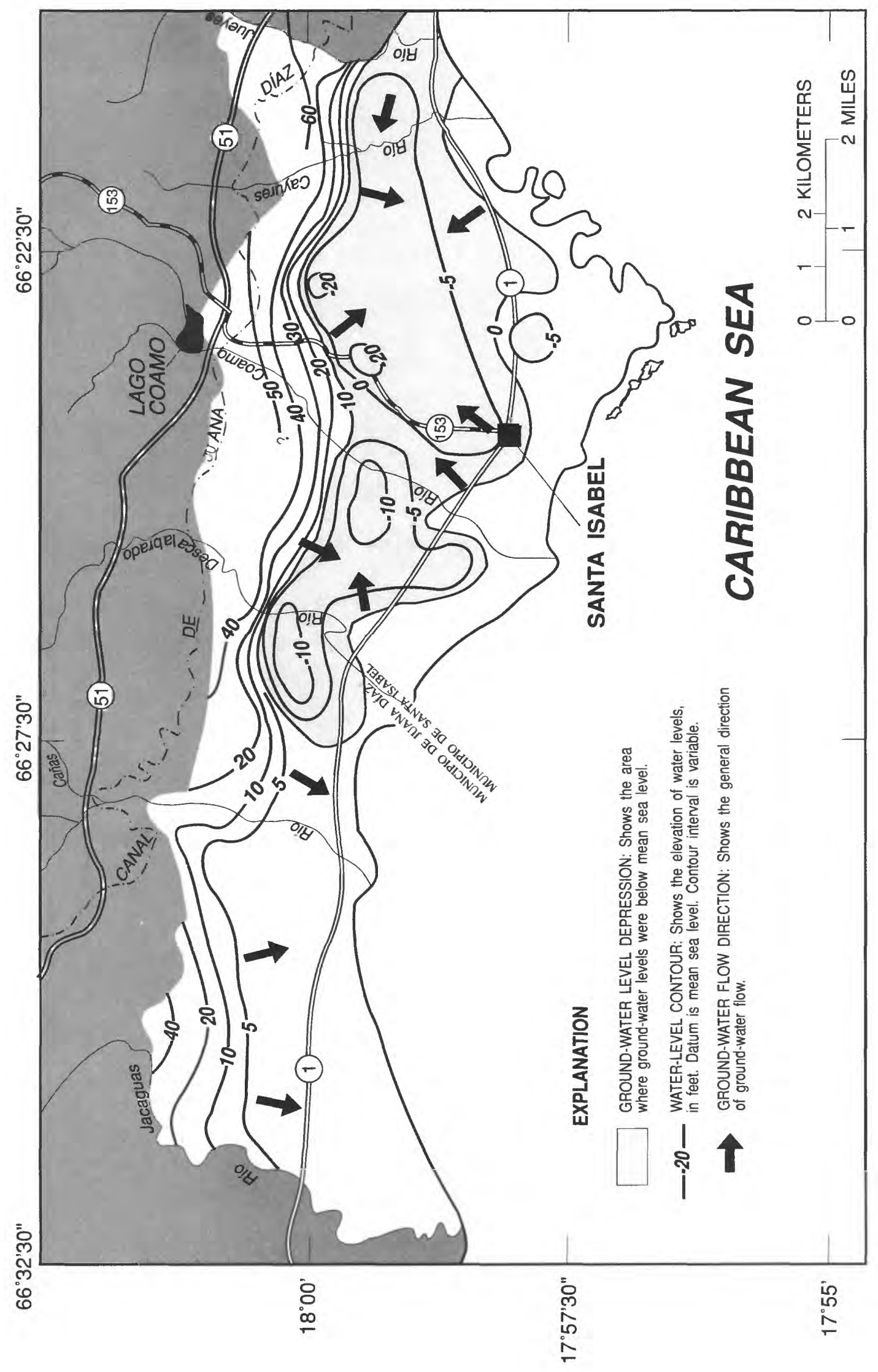

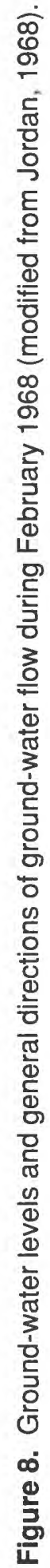


was calculated assuming an average depth to water of about $6 \mathrm{ft}$, which, according to the empirical relation, yields an evapotranspiration rate of $0.001 \mathrm{ft} / \mathrm{d}$.

\section{HYDROLOGIC CONDITIONS DURING A PERIOD OF DRIP IRRIGATION}

With the conversion from furrow to drip irrigation, the dependance on surface-water deliveries from the Canal de Juana Díaz and the amount of ground water withdrawn from the alluvial aquifer decreased. About 80 percent of the dripirrigation plan, which consider the installation of the drip method on all wells used for irrigation (Puerto Rico Department of Agriculture, 1984), had been implemented, and streamflow deliveries had been almost completely discontinued by 1987 . In 1987 , only a small amount of land $\left(8 \mathrm{mi}^{2}\right)$ in the study area was still planted in sugarcane (fig. 5) and irrigated by furrow methods with water from Canal de Juana Díaz and water withdrawn from the alluvial aquifer.

During 1985 to 1987 , ground-water levels in the study area fluctuated seasonally by as much as $10 \mathrm{ft}$ (fig. 9) in response to a decrease in aquifer recharge by rainfall and streamflow seepage and an increase in pumpage during January to April and June to September (dry periods). During the wet periods of May and October-November 1987, the ground-water levels were higher because of increased aquifer recharge and decreased pumpage. The highest water levels in most observation wells in the study area (sites $8,9,10,11$, and 12) occurred during October 1985 . These high water levels were the result of the large amount of water that infiltrated to the aquifer during the floods of October 5-10, 1985. Most water-level fluctuations during the period $1985-87$ were the result of pumping for irrigation.

The configuration of the water table in the alluvial aquifer during March and April 1987 is shown in figure 10. The water levels measured during that period are considered representative of average conditions. Data from 1967 to 1987 (20 years) at well site 9 (fig. 9) indicated an average water level of $29.2 \mathrm{ft}$ below land surface with a standard deviation of $6.98 \mathrm{ft}$. The mean water level for March-April 1987 at this site was within one standard deviation of the mean value for 1967 to 1987.

Ground-water levels during 1987 ranged from $5 \mathrm{ft}$ above mean sea level near the coast to about $50 \mathrm{ft}$ above mean sea level near the northern boundary of the study area (fig. 9). The water level was as high as $5 \mathrm{ft}$ above mean sea level at distances about $1 \mathrm{mi}$ inland from shore. The general direction of ground-water movement in 1987 was toward the coast and the hydraulic gradient in the aquifer near the coast was about
$9 \mathrm{ft} / \mathrm{mi}$ and $7 \mathrm{ft} / \mathrm{mi}$ for areas west and east of the Río Descalabrado, respectively. There were no large cones of depression in the water table in 1987.

Aquifer discharge was estimated to be about $27 \mathrm{Mgal} / \mathrm{d}$ and ground-water pumpage was the principal outflow component of the water budget for the alluvial aquifer during 1987. The average ground-water withdrawal during 1987 was about 21 $\mathrm{Mgal} / \mathrm{d}$. Ground-water withdrawals from the alluvial aquifer for drip irrigation totaled about $9 \mathrm{Mgal} / \mathrm{d}$ and withdrawals for furrow irrigation totaled about $8 \mathrm{Mgal} / \mathrm{d}$. Ground-water withdrawals for public and domestic water supply totaled about $4 \mathrm{Mgal} / \mathrm{d}$. Ground-water flow to the sea was estimated to be 5.7 Mgal/d. This flow estimate is based on the average hydraulicgradient near the coast in areas west and east of the Río Descalabrado ( 9 and $7 \mathrm{ft} / \mathrm{mi}$, respectively); aquifer transmissivity values for these areas $\left(4,000\right.$ and $11,000 \mathrm{ft}^{2} / \mathrm{d}$, respectively) and the cross-sectional length of the areas (42,500 and $32,500 \mathrm{ft}$, respectively).

Aquifer recharge during 1987 was estimated to be about 27 $\mathrm{Mgal} / \mathrm{d}$. This estimate was based on a ground-water level survey and a seepage study of the Canal de Juana Díaz and of the streams flowing through the study area during April 1987. Rainfall recharge was estimated to average about $11 \mathrm{Mgal} / \mathrm{d}$ (10 percent of the 1985-87 average-annual rainfall in the study area). The net aquifer recharge by stream seepage (fig. 11), calculated as the difference between stream inflows and outflows, during April 1987 was estimated to be $9.4 \mathrm{Mgal} / \mathrm{d}$. the Río Jacaguas, the Río Cañas, and the Río Coamo contributed more recharge than the other streams that flow through the study area. The Río Jacaguas contributed more than half the recharge from streams, about $5.1 \mathrm{Mgal} / \mathrm{d}$. Recharge from water used to irrigate crops in furrow-irrigated lands was estimated to be about $6.6 \mathrm{Mgal} / \mathrm{d}$. Approximately 2.4 $\mathrm{Mgal} / \mathrm{d}$ (30 percent of the $8 \mathrm{Mgal} / \mathrm{d}$ of ground water used for furrow irrigation) came from ground water applied to those parts of the study area. For this estimate of recharge, it was assumed that there was no aquifer recharge in drip-irrigated areas. Aquifer recharge from seepage of water through Canal de Juana Díaz was estimated to be $4.2 \mathrm{Mgal} / \mathrm{d}$ ( 30 percent of the $14 \mathrm{Mgal} / \mathrm{d}$ of water diverted for irrigation in the study area).

Evapotranspiration in 1987 was estimated as the residual of the inflow and outflow terms of the water budget, and accounted for approximately $0.3 \mathrm{Mgal} / \mathrm{d}$. The difference between estimated total aquifer recharge of $27 \mathrm{Mgal} / \mathrm{d}$ and the estimated total outflows of $26.7 \mathrm{Mgal} / \mathrm{d}$ was $0.3 \mathrm{Mgal} / \mathrm{d}$ and was assumed to represent evapotranspiration. 

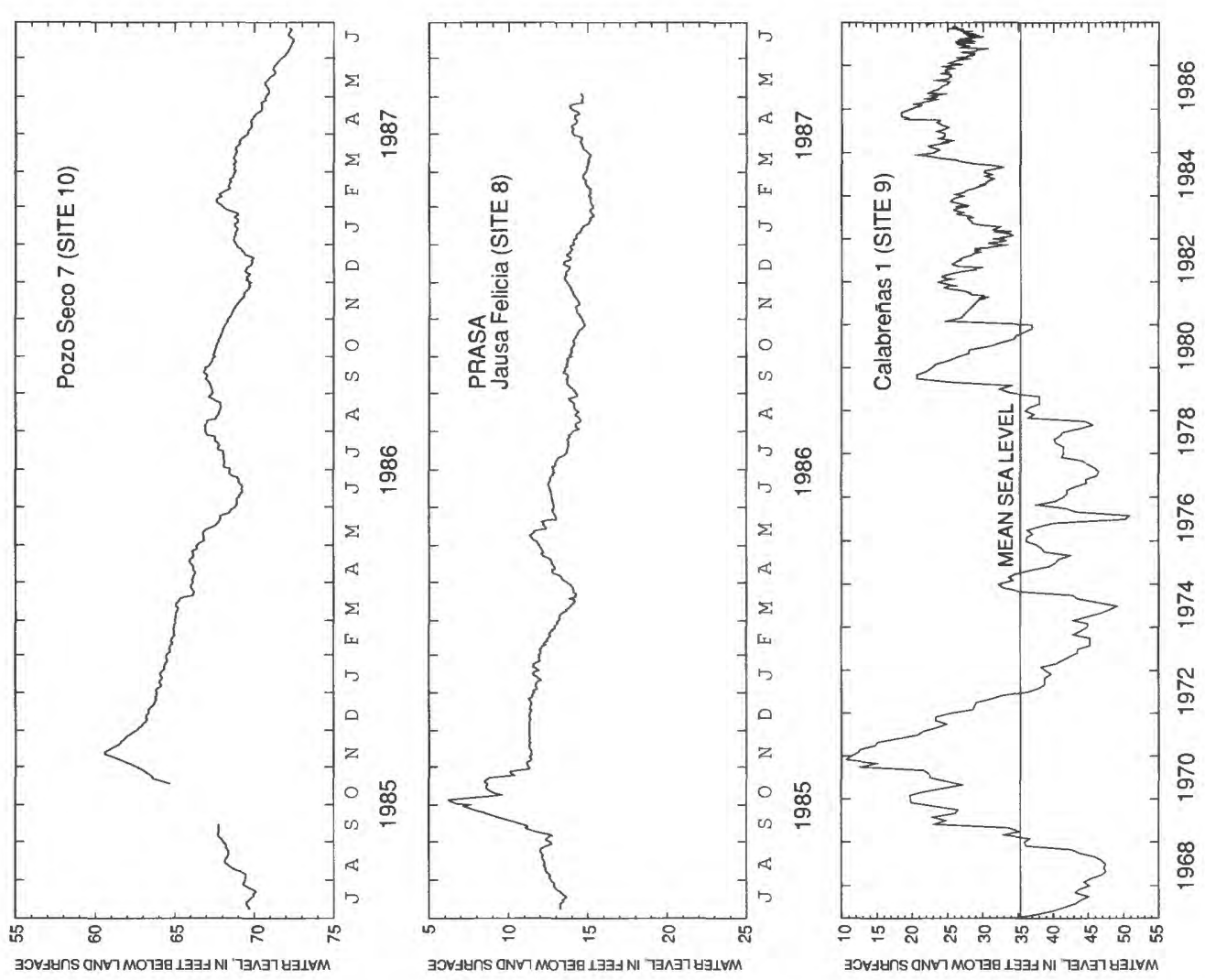

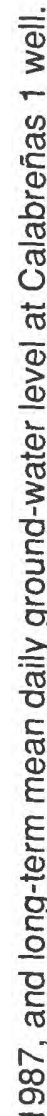
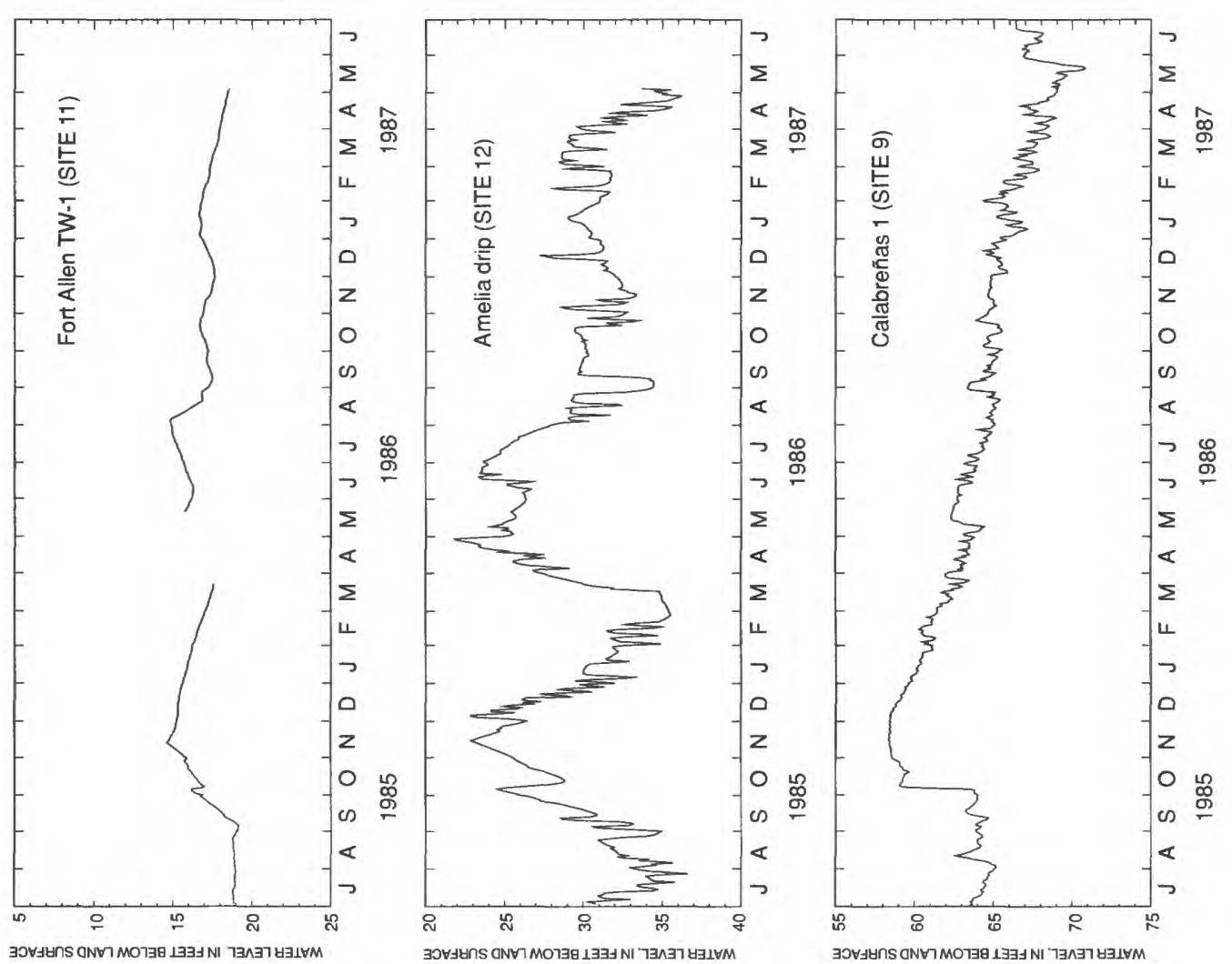

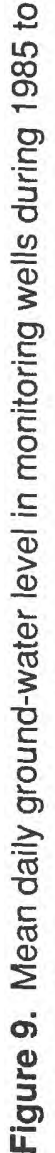




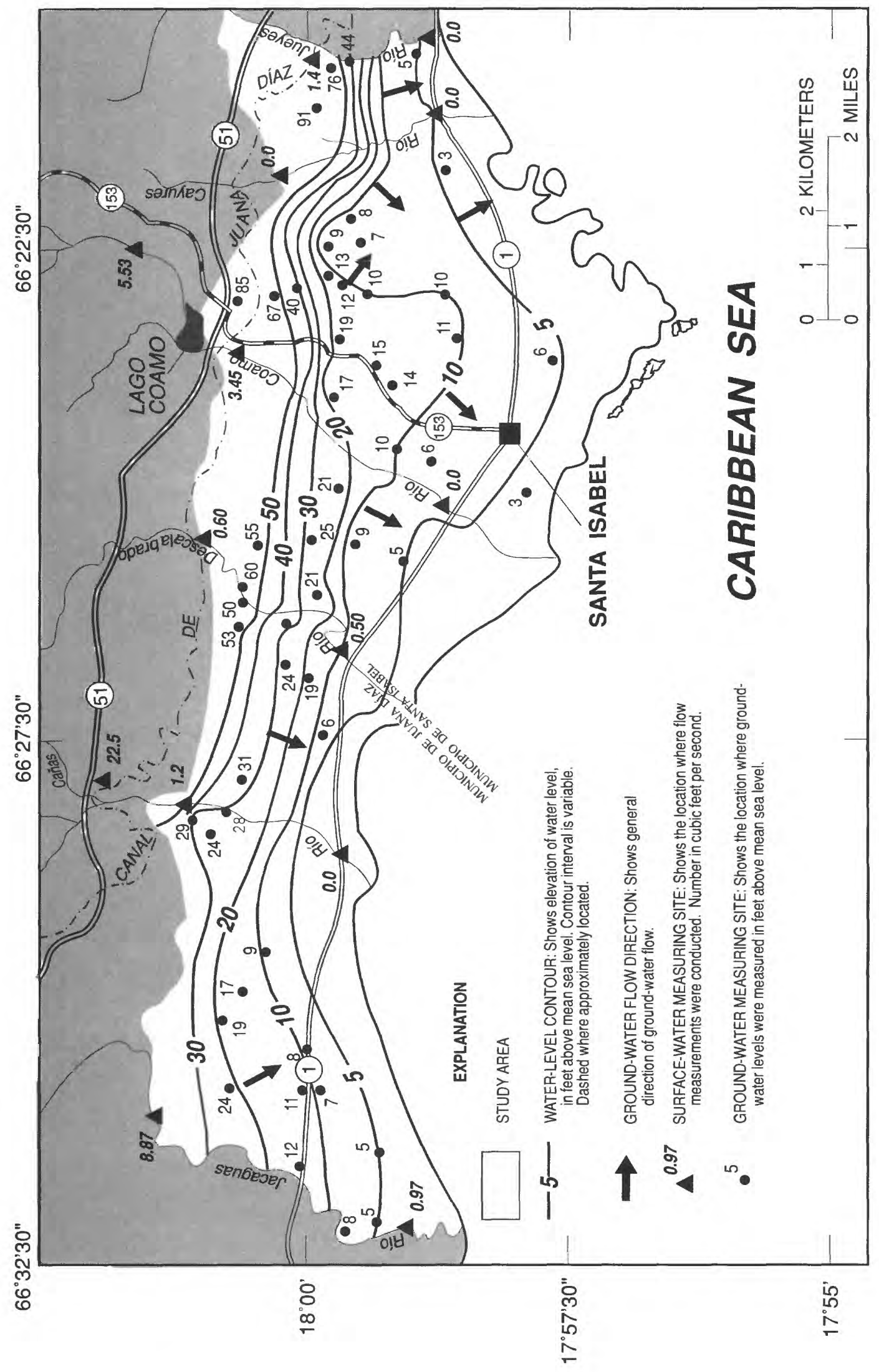

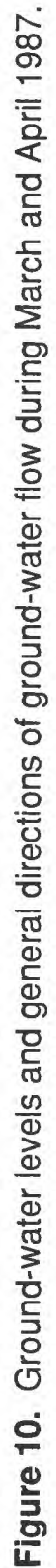




\section{EFFECTS OF CHANGING IRRIGATION PRACTICES ON THE GROUND-WATER HYDROLOGY}

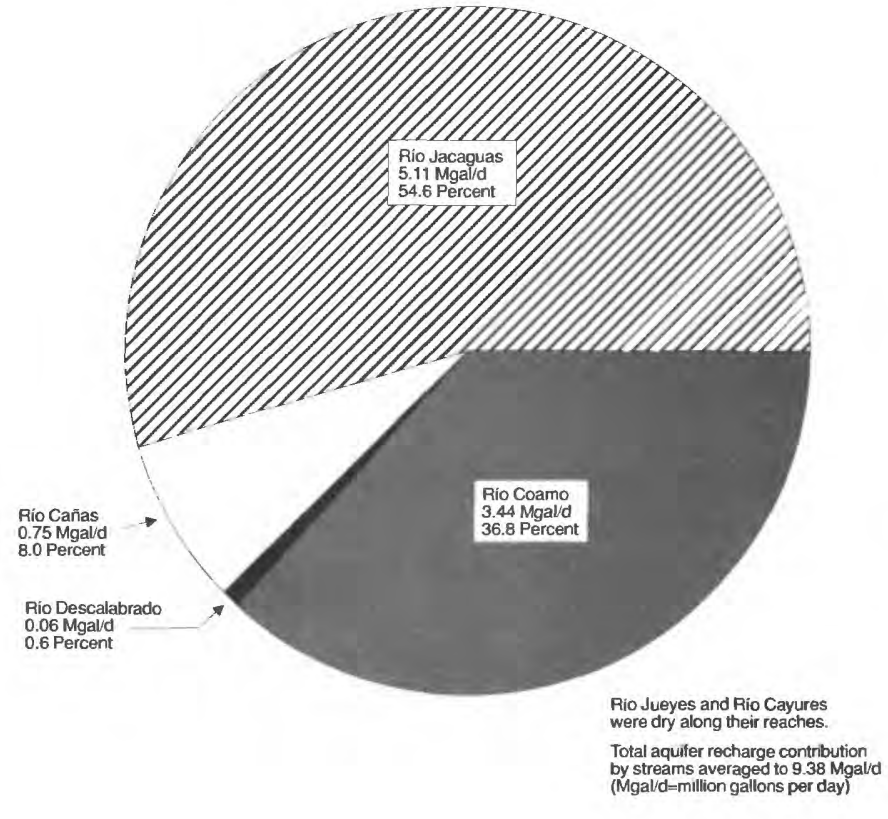

Figure 11. Net contribution of streams to the aquifer recharge during April 1987.

In 1987, chloride concentrations were as low as $40 \mathrm{mg} / \mathrm{L}$ in water from wells less than $1 \mathrm{mi}$ from the coast (fig. 12). Chloride concentration ranged from approximately 30 to 400 $\mathrm{mg} / \mathrm{L}$ with the highest concentrations in water from wells along the coast and near outcrops of the Juana Díaz Formation. Concentrations as high as $179 \mathrm{mg} / \mathrm{L}$ were found near outcrops of the Juana Díaz Formation, which might indicate highchloride ground-water seepage from this formation to the alluvial aquifer.

Chloride concentrations in water from wells screened at various depths indicate that the saline-freshwater interface in the aquifer may be at depths greater than $50 \mathrm{ft}$ below land surface along the coast and probably more than $700 \mathrm{ft}$ below land surface at a distance of $1 \mathrm{mi}$ from the coast. South of highway 1, the chloride concentrations ranged from 24 to 400 $\mathrm{mg} / \mathrm{L}$ (fig. 12). A chloride concentration of $400 \mathrm{mg} / \mathrm{L}$ was detected in water sampled at a pumped well just a few feet from shore east of Santa Isabel.
The immediate hydrologic effect of the change from furrow to drip irrigation was a decrease in the amount of aquifer recharge from water used for furrow irrigation. During the period of furrow irrigation, irrigation water applied to the crops was the principal source of aquifer recharge in the study area (table 2). Aquifer recharge from irrigation water was about 18.7 Mgal/d prior to ground-water development and about 37 $\mathrm{Mgal} / \mathrm{d}$ in 1966-68 when furrow irrigation was the principal method of irrigation. In 1987, when the conversion from furrow to drip irrigation was nearly complete, the estimated aquifer recharge from irrigation water was about $6.6 \mathrm{Mgal} / \mathrm{d}$, a decrease in aquifer recharge of about $30.4 \mathrm{Mgal} / \mathrm{d}$. The aquifer recharge from irrigation in 1987 was primarily in the remaining sugarcane fields where furrow irrigation was still used.

Although aquifer recharge was substantially reduced as a result of the implementation of drip irrigation, the aquifer water-levels were higher in 1987 than in 1966-68 because of the substantial decrease in ground-water withdrawals and subsequent recovery of ground-water levels. Withdrawals from the alluvial aquifer for irrigation totaled about $8.4 \mathrm{Mgal} / \mathrm{d}$ prior to substantial ground-water development and about $77 \mathrm{Mgal} / \mathrm{d}$ in 1966-68 after ground-water development had occurred. In 1987 , the estimated average pumpage for irrigation had been reduced to about $17 \mathrm{Mgal} / \mathrm{d}$, a decrease of about $60 \mathrm{Mgal} / \mathrm{d}$ since 1966-68. The 1987 pumpage was about $8.6 \mathrm{Mgal} / \mathrm{d}$ greater than that during the predevelopment period. The change from furrow- to drip-irrigation methods was not the only reason ground-water withdrawals decreased. Withdrawals were reduced from about $31 \mathrm{Mgal} / \mathrm{d}$ to about $24 \mathrm{Mgal} / \mathrm{d}$ in 1974 (fig. 13) to stop or slow the inland movement of saline water into the aquifer (J.R. Díaz, U.S. Geological Survey, unpublished data, 1974b).

Ground-water levels in the central part of the study area were $15 \mathrm{ft}$ higher in 1987 than in 1966-68 and about $10 \mathrm{ft}$ lower than in 1930. The ground-water flow to sea increased during the period 1966-68 to 1987 as a result of higher ground-water levels. Ground-water flow to sea was about 5.2 Mgal/d higher in 1987 than in 1966-68, but was about 11.3 lower than in 1930 .

Chloride concentrations in water from wells near the coast were lower in 1987 than in 1966-68, due to the increase in ground-water flow to the sea. The chloride concentration in the alluvial aquifer decreased from about $250 \mathrm{mg} / \mathrm{L}$ in $1966-68$ to about $40 \mathrm{mg} / \mathrm{L}$ in 1987 at distances of less than $1 \mathrm{mi}$ from shore. However, the chloride concentrations were higher in 1987 than in 1930 . 


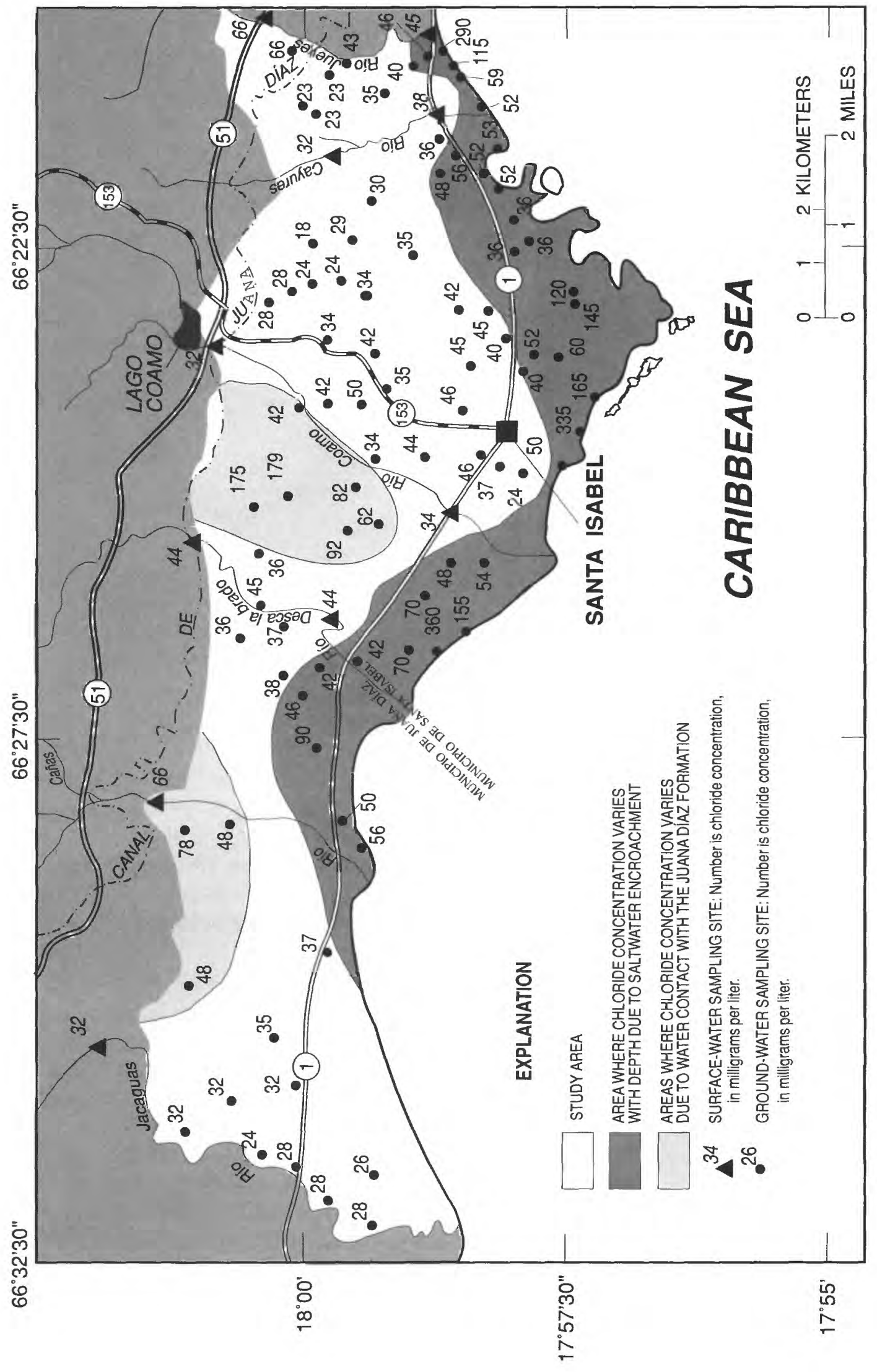

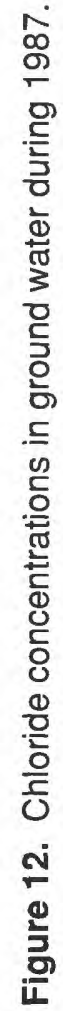


Table 2. Summary of aquifer recharge and discharge prior to ground-water development and during periods of furrow irrigation and drip irrigation

[Values in million gallons per day, except where specified]

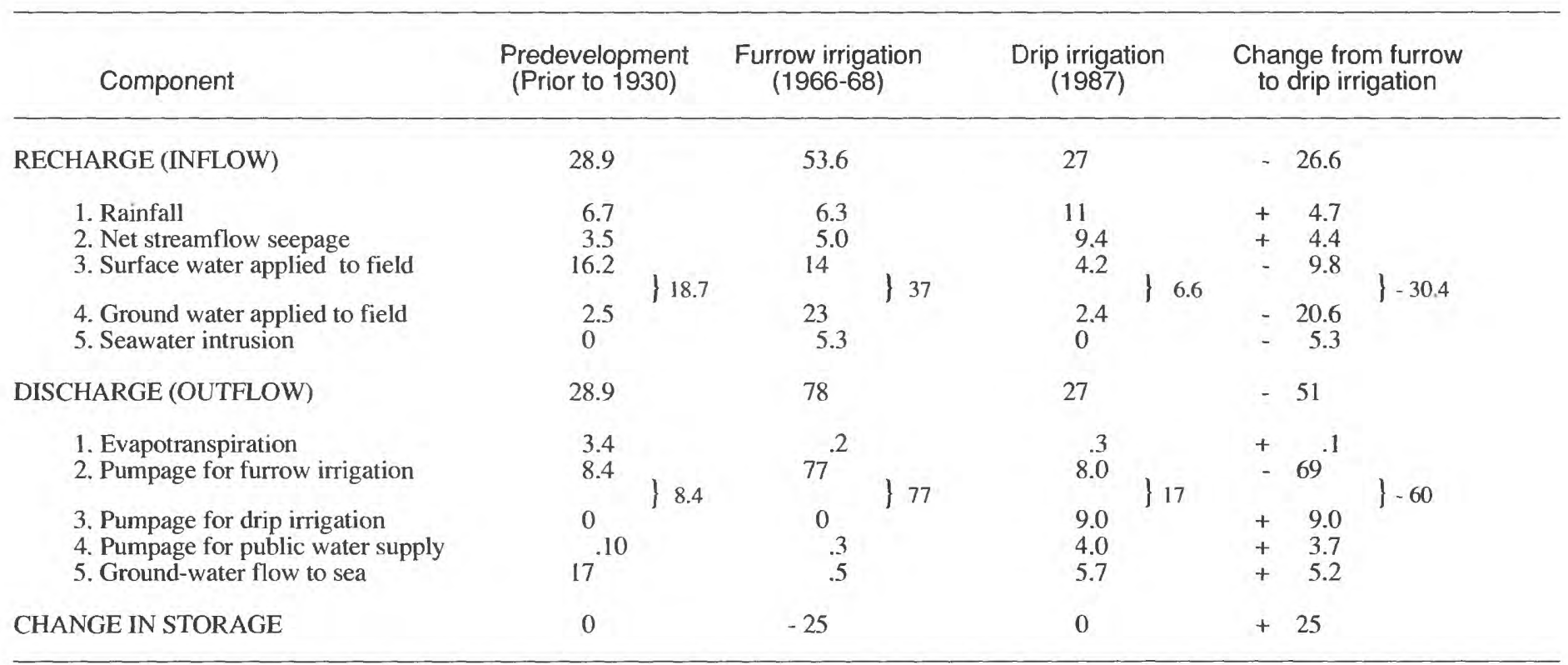

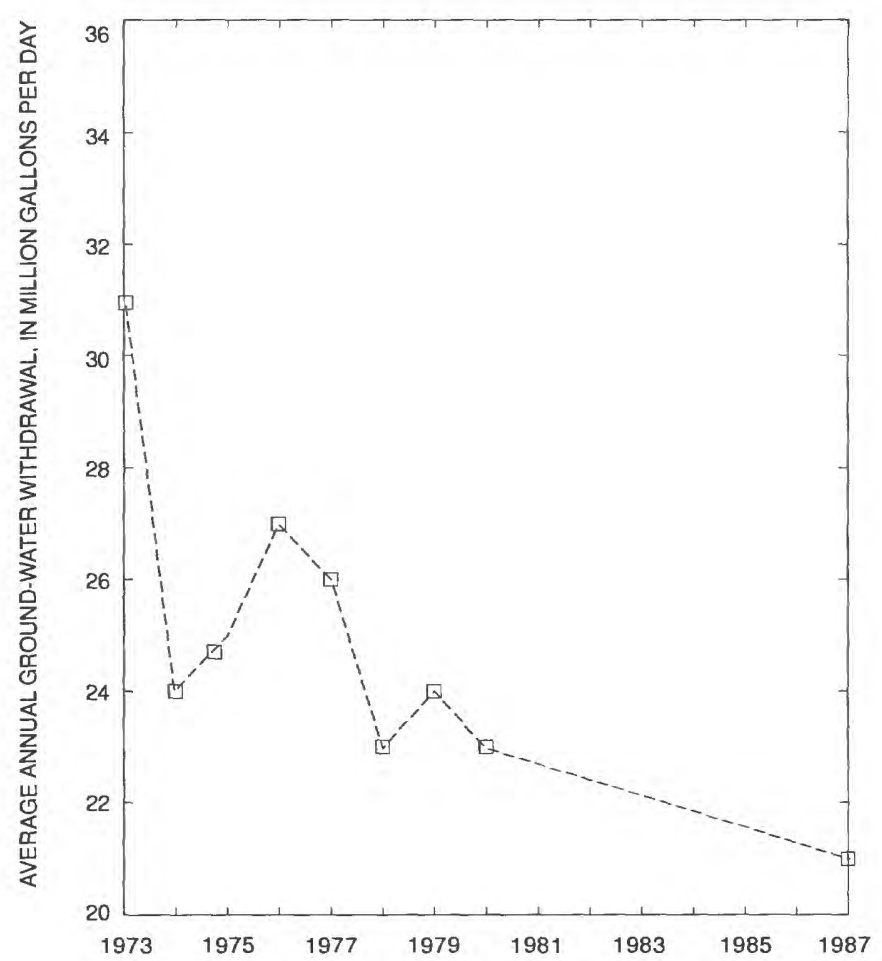

Figure 13. Estimated average annual ground-water withdrawals, 1973 to 1987.

\section{SUMMARY}

Irrigation practices in the Santa Isabel-Juana Díaz area have changed from primarily furrow to primarily drip irrigation. An assessment of the effects of the changes in irrigation practices in the Santa Isabel-Juana Díaz area was made by comparing hydrologic conditions during periods prior to the development of ground water, during a period of furrow irrigation when much of the water used was ground water, and during a period when drip irrigation was the predominant method of irrigation.

Ground-water development was insignificant prior to 1930 , when water demand was met with surface-water deliveries supplied through a complex channel-pond irrigation system. Hydrologic conditions in 1930 were considered representative of conditions prior the development of the ground-water system. The hydrologic conditions in 1966-68 were considered representative of conditions during periods when surface and ground water were used for furrow irrigation in the study area. During the period when ground water was used extensively for furrow irrigation, the aquifer was overdeveloped and water levels were below mean sea level in much of the eastern part of the study area.

The immediate effect of the change from furrow to drip irrigation and a reduction in ground-water pumpage was a decrease in the aquifer recharge from irrigation water. Aquifer recharge from irrigation water was about $18.7 \mathrm{Mgal} / \mathrm{d}$ in 1930 , 
prior to ground-water predevelopment, and about $37 \mathrm{Mgal} / \mathrm{d}$ in 1966-68 when large amounts of surface and ground water were used for furrow irrigation. In 1987, when the conversion from furrow to drip irrigation was almost completed, estimated aquifer recharge by irrigation water was about $6.6 \mathrm{Mgal} / \mathrm{d}$. Most of the recharge from irrigation water in 1987 occurred in the few remaining sugarcane fields where furrow irrigation was still used.

Although aquifer recharge was substantially reduced as a result of the implementation of drip irrigation, the water-levels in the aquifer were higher in 1987 than in 1966-68 because of the substantial decrease in ground-water withdrawals and subsequent recovery of the water levels. Ground-water withdrawals for irrigation decreased from about $77 \mathrm{Mgal} / \mathrm{d}$ in 1966-68 to about $17 \mathrm{Mgal} / \mathrm{d}$ in 1987. By 1987, the decrease in withdrawals of water from the aquifer had resulted in ground water flow toward the sea thereby eliminating the seawater intrusion into the aquifer that had occurred in the late 1960's.

Chloride concentrations in water from wells near the coast were lower in 1987 than in 1966-68. The chloride concentrations in water in the aquifer decreased from about $250 \mathrm{mg} / \mathrm{L}$ in 1966-68 to about $40 \mathrm{mg} / \mathrm{L}$ in 1987 at distances of less than $1 \mathrm{mi}$ from the seashore. In 1987, chloride concentration indicated that the saline-freshwater interface in the aquifer probably was at depths greater than $50 \mathrm{ft}$ below land surface along the coast and more than $700 \mathrm{ft}$ below land surface, inland from the coast.

\section{REFERENCES}

Album de Oro de Puerto Rico, 1939, Obra de divulgación cultural en pro de la fraternidad americana, $540 \mathrm{p}$.

Bennett, G.D., 1976, Electrical analog simulation of the aquifers along the south coast of Puerto Rico: U.S. Geological Survey Open-File Report 74-4, 101 p.

Bogart, D.B., Arnow, Ted, and Crooks, J.W., 1964, Water resources of Puerto Rico - A progress report: U.S. Geological Survey Water-Resources Bulletin 4, 120 p.

Brown, R.H., 1963, Estimating the transmissibility of an artesian aquifer from specific capacity of a well: in Bentall, R., Methods of determining permeability, transmissibility, and drawdown, U.S. Geological Survey Water-Supply Paper 1536-I, p. 336-338.

Colón-Dieppa, Eloy, and González, J.R., 1981, Ground-water levels in alluvium on the south coast of Puerto Rico, February 1979: U.S. Geological Survey Open-File Report 81-641,21 p.
Colón-Ramos, Héctor, and Colón-Dieppa, Eloy, 1981, Groundwater levels and chloride concentrations in alluvial aquifers on the south coast of Puerto Rico, February 1980: U.S. Geological Survey Open-File Report 81-626, 20 p.

Díaz, J.R., 1974, Coastal salinity reconnaissance and monitoring system, south coast of Puerto Rico: U.S. Geological Survey Open-File Report 74-1, 28 p.

1977a, Ground-water levels on the south coast of Puerto Rico, February 1974 to February 1975: U.S. Geological Survey Open-File Report 76-625, 30 p.

1977b, Ground-water in alluvium on the south coast of Puerto Rico, February 1977: U.S. Geological Survey Open-File Report 77-696, 6 p.

1979a, Ground-water level in alluvium on the south coast of Puerto Rico, February 1978: U.S. Geological Survey Open-File Report 79-1272, 18 p.

1979b, Seawater intrusion, south coast of Puerto Rico, 1966-77: U.S. Geological Survey Open-File Report 79$1334,20 \mathrm{p}$.

Giusti, E.V., 1968, Water resources of the Juana Díaz area, Puerto Rico - A preliminary appraisal 1966: U.S. Geological Survey Water-Resources Bulletin 8, 43 p.

1971a, Regional specific yield of Coamo Fan, Puerto Rico, computed by water budget method: in Geological Survey Research 1971, Chap. B, U.S. Geological Survey Professional Paper 750-B, p. 248-251.

1971b, Water resources of the Coamo area, Puerto Rico: U.S. Geological Survey Water-Resources Bulletin 9,31 p.

Glover, Lynn, 1961a, Preliminary geologic map of the Salinas quadrangle, Puerto Rico: U.S. Geological Survey Miscellaneous Geologic Investigations Map 1-337, 1 pl.

$1961 \mathrm{~b}$, Preliminary report on the geology of the Coamo quadrangle, Puerto Rico: U.S. Geological Survey Miscellaneous Geologic Investigations Map I-335, 1 pl.

1971, Geology of the Coamo area, Puerto Rico and its relation to the volcanic arc-trench association: U.S. Geological Survey Professional Paper 636, 102 p.

Glover, Lynn, and Mattson, P.H., 1973, Geologic map of the Río Descalabrado quadrangle, Puerto Rico: U.S. Geological Survey Miscellaneous Geologic Investigations Map I-735, 1 pl. 
Heisel, J.E., and González, J.R., 1976, Ground-water levels on the south coast of Puerto Rico, February 1976: U.S.

Geological Survey Open-File Report 76-705, 13 p.

1979, Water budget and hydraulic aspects of artificial recharge, south coast of Puerto Rico: U.S. Geological Survey Water-Resources Investigations Report 78-58, $102 \mathrm{p}$.

Krushensky, R.D., and Monroe, W.H., 1975, Geologic map of the Ponce quadrangle, Puerto Rico: U.S. Geological Survey Miscellaneous Investigations Map 1-863, 1 pl.

Luchetti, T.H., 1969, Breve reseña sobre los sistemas de riego público en Puerto Rico; Red Agrícola de Puerto Rico: v. 50, no. 2, July-December 1963, p. 66-87.

McGuinness, C.L., 1946, Records of wells in Puerto Rico: U.S. Geological Survey Open-File Report, 267 p.

1948, Ground-water resources of Puerto Rico: U.S. Geological Survey Open-File Report, 613 p.

Monroe, W.H., 1980, Geology of the middle Tertiary Formations of Puerto Rico: U.S. Geological Survey Professional Paper 953, 93 p.
Puerto Rico Department of Agriculture, 1984, Master plan for drip irrigation: Corporación de Vegetales Inc., 120 p.

Rodríguez-del-Río, Félix, and Gómez-Gómez, Fernando, 1990, Potentiometric surface of the alluvial aquifer and hydrologic conditions in the Santa Isabel-Juana Díaz area, Puerto Rico, March to April 1987: U.S. Geological Survey WaterResources Investigations Report 89-4116, 1 sheet.

Theis, C.V., 1963, Estimating the transmissibility of a watertable aquifer from the specific capacity of a well: in Bentall, R., Methods of determining permeability, transmissibility, and drawdown, U.S. Geological Survey Water-Supply Paper 1536-1, p. 336-338.

U.S. Department of Agriculture, 1934, Climatic Summary of the United States, Weather Bureau, Section 106, p. 1-20.

Ward, P.E.,3 and Truxes, C.S., 1964, Water wells in Puerto Rico: U.S. Geological Survey Water-Resources Bulletin 3, $249 \mathrm{p}$.

Yamauchi, H., 1984, Impact on ground-water resources of conversion from furrow to drip irrigation: Water-Resources Bulletin No. 4, v. 20, p. 557-563. 